\title{
Research Article \\ Biodiversity of Three Backwaters in the South West Coast of India
}

\author{
Beslin Leena Grace \\ Department of Biotechnology, Vinayaka Missions University, Salem, Tamil Nadu 636308, India \\ Correspondence should be addressed to Beslin Leena Grace; leenagrace_2002@yahoo.com
}

Received 3 August 2014; Revised 13 November 2014; Accepted 13 November 2014; Published 9 December 2014

Academic Editor: Alexandre Sebbenn

Copyright (C) 2014 Beslin Leena Grace. This is an open access article distributed under the Creative Commons Attribution License, which permits unrestricted use, distribution, and reproduction in any medium, provided the original work is properly cited.

For the conservation of biodiversity, it is not sufficient to preserve the living organisms or their gametes alone, because keeping fishes in aquaria or their gametes in freezers cannot conserve the full range of biodiversity which is due to the loss of the ecological complexity in their original habitats. For promoting richer biodiversity in the future, more complexity in biological communities is essential in their natural environments. In order to prevent depletion of biodiversity due to environmental alterations or other ways, it is necessary to understand how the diversity of life particularly at the species level is maintained and it is equally necessary to know how the terminal extinction of species takes place under natural conditions. Moreover, a database on fishery resources of the concerned environment is essential to make decision about specific programmes on conservation of fish germplasm resources. Hence, the present study aims to quantify the fish and shellfish resources of the selected backwaters such as Kadinamkulam, Veli, and Poonthura to know the real stocks present in such environments.

\section{Introduction}

Biodiversity is the basis of human survival and economics which encompasses all life forms, ecosystems, and ecological processes showing hierarchy at genetic taxon and ecosystem levels. Mass extinction due to the continued increase of human population and alteration of several ecosystems leads to the impairment of diversity patterns. The genetic diversity in a population is the result of the random occurrence of conservative replication of preexisting gene forms and combinations, sudden phenotypic differences due to mutation and recombination, the positive or negative selection enforced by external pressures, and the random events affecting specific individuals during the origin of the particular group [1]. Decisions regarding creation and management of various kinds of reserves are likely to be the key factors in determining the long term future of biodiversity. Ecological complexity enhances biodiversity through evolutionary and biogeographical processes and its degradation quickly causes the diversity in phenotypic and genotypic traits to decline. The greatest impact on species deletions will be in those systems where there is limited number of representatives of a particular functional group especially if the species is a dominant one [2].
A variety of indices are available to measure the diversity of biological communities. These indices assume the biological diversity which can be satisfactorily described by two major components such as the number of species and their relative abundance. These indices treat all species as equivalent and ignore taxonomic, morphological, or any such biological differences among species of a community [3]. In studies investigating diversity partitioning among sites, biodiversity indices are almost exclusively based on species composition even though the definition of biodiversity includes various facets of the diversity of life [4].

An outstanding feature of the Kerala's coastal zone is the presence of a large number of perennial or temporary estuaries popularly known as backwaters. Thirty backwaters occur along the $590 \mathrm{~km}$ long coast of Kerala covering an estimated area of around 2, 42,000 ha. An important feature of backwaters is their biological diversity, which refers to the diversity of various species of living organisms. Such diverse combinations of living organisms and ecological services constitute the natural resource entitlements of the local communities. The wide variety of fish and shellfish resources, aquaculture systems, brackish water agriculture, mangroves, and innumerable forms of microorganisms are directly useful and 


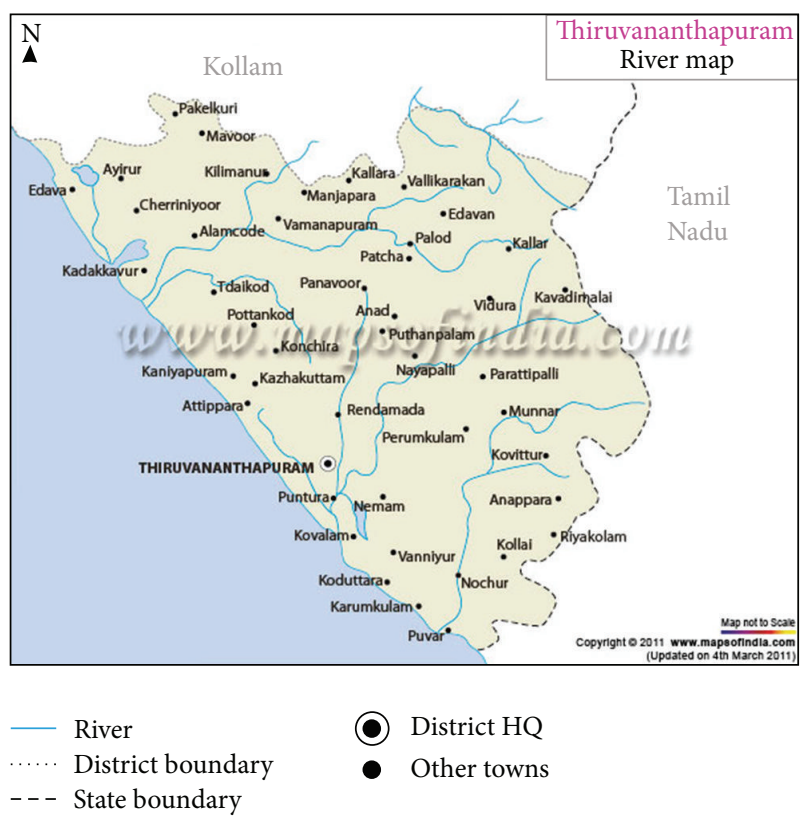

FIgURE 1: Map showing study sites.

sustain the economy of local population. Kerala is endowed with a rich diversity of marine fishes with a numerical strength of more than 300 . They represent mainly clupeids, perches, elasmobranchs, leiognathids, croakers, threadfin breams, flat fishes, carangids, red mullets, and so forth. There are about 54 species of prawns and shrimps commercially exploited in India [5]. The present scenario of the estuarine systems of Kerala has been exhibiting signs of impaired ecological health due to the extensive hydrological alteration, agricultural land use, and increasing watershed development. In order to prevent depletion of biodiversity due to environmental alterations or other ways, it is necessary to understand how the diversity of life particularly at the species level is maintained and it is equally necessary to know how the terminal extinction of species takes place under natural conditions. Due to these factors, the present study aims to characterize the nature of biodiversity loss in selected backwaters and to find out the major causes of biodiversity erosion and to document these processes in detail.

\section{Description of Study Sites}

For the present study, three sites, namely, (1) Kadinamkulam backwater, (2) Veli lake, and (3) Poonthura backwater, were selected (Figure 1).

(1) Kadinamkulam Backwater. This backwater (latitude of $8^{\circ} 35^{\prime}-8^{\circ} 40^{\prime} \mathrm{N}$ and a longitude of $76^{\circ} 45^{\prime}-76^{\circ} 52^{\prime} \mathrm{E}$ ) lies almost parallel to the adjoining Laccadive Sea for some distance and has a temporary connection with the sea at the north western region. It is the largest among the backwaters of Trivandrum district. The Vamanapuram River originating from the Western Ghats, after traversing for about $80 \mathrm{~km}$ and covering a drainage area of $540 \mathrm{~km}^{2}$, empties into the backwater through Anchuthengu Lake. The nature of the mouth depends on the extent of sand bar formation and it normally gets closed completely for varying periods during the premonsoon with the diminishing freshwater discharge.

(2) Veli Lake. It is the smallest among the backwaters of Kerala. It is situated $8 \mathrm{~km}$ northwest of Trivandrum City at $8^{\circ} 28^{\prime} \mathrm{N}$ latitude and $76^{\circ} 57^{\prime} \mathrm{E}$ longitude. The system widens from the bar mouth to the eastern part and is $2 \mathrm{~km}$ long and $0.3 \mathrm{~km}$ broad. It is connected to the Kadinamkulam backwater through Parvathy Puthanar canal. On the southern side, it is connected with the Chackai canal and AKkulam Lake. The Veli Lake is shallow with a mean depth of 2$3 \mathrm{~m}$. Unlike other large backwaters, it has no permanent connection with the sea. During the monsoon season, the hydraulic pressure breaks open the bar mouth resulting in maintaining a temporary connection with the adjoining sea.

(3) Poonthura Backwater. It is situated about $5.6 \mathrm{~km}$ south of the international airport at Thiruvananthapuram (latitude between $8^{\circ} 25^{\prime}$ and $8^{\circ} 3^{\prime} \mathrm{N}$ and longitude between $76^{\circ} 55^{\prime}$ and $77^{\circ} 00^{\prime} \mathrm{E}$ ). It is a typical estuary, circular in shape, and enclosing an island called Edayar. The total length of the estuary is $4.35 \mathrm{~km}$ and the mean width is $0.1 \mathrm{~km}$. This is separated from the Lakshadweep Sea by a sand bar at Poonthura which opens during the monsoon period consequent to heavy discharge of water from the Karamana River. The Parvathy Puthanar canal, through which the sewage spilled from the sewage farm situated at Muttathara, reaches the Poonthura estuary.

\section{Material and Methods}

Monthly survey of finfishes and the shellfishes of the three backwaters such as Kadinamkulam, Veli, and Poonthura of Kerala coast was carried out in the present study. The sampling sites were chosen due to the impairment of water quality by coir retting and pesticide mixed agricultural run-off. All specimens were sorted at the species level and were counted and weighed on board. Only fish were included in the analysis. The same net was used for all sampling; the mesh size for the net opening was $6.3 \mathrm{~cm}$, the depth of the net opening was $6 \mathrm{~m}$, the width of the net opening was $22.6 \mathrm{~m}$, the mesh size of the cod end was $2 \mathrm{~cm}$, and the trawling speed was approximately $4.82 \mathrm{~km} / \mathrm{h}$ (2.6 knots). The survey was carried out in fresh morning during $4 \mathrm{am}$. Every month three surveys were taken and made into mean values. Each species was counted separately. The fishes needed for identification were taken as samples. Samples of fishes and shellfishes were preserved in $4 \%$ formalin for identification. Identification of fishes was carried out using standard keys $[6,7]$. Stratified random sampling method was followed to assess the count of each species. The survey study was carried out for a period of one year (April 2012 to March 2013). Statistical analyses for diversity index, diversity richness, evenness, and biodiversity dominance were carried out to count the biodiversity criteria [8].

Biodiversity is the variation of life forms within a given ecosystem, biome, or the entire Earth. Biodiversity is often used as a measure of the health of biological systems [9]. To understand different biodiversity indices used in the study, they are categorized as follows. 
3.1. Diversity Index. A diversity index is a mathematical measure of species diversity in a community. Diversity indices provide more information about community composition than simply species richness (i.e., the number of species present); they also take the relative abundances of different species into account. Diversity indices provide important information about rarity and commonness of species in a community. The ability to quantify diversity in this way is an important tool for biologists trying to understand community structure.

Variables are as follows:

\section{$H$ : Shannon's diversity index;}

$S$ : total number of species in the community (richness);

$p_{i}:$ proportion of $S$ made up of the $i$ th species;

$E_{H}$ : equitability (evenness).

The proportion of species $i$ relative to the total number of species $\left(p_{i}\right)$ is calculated and then multiplied by the natural logarithm of this proportion $\left(\ln p_{i}\right)$. The resulting product is summed across species and multiplied by -1 as follows:

$$
H=-\sum_{i=1}^{S} p_{i} \ln p_{i} .
$$

Shannon's equitability $\left(E_{H}\right)$ can be calculated by dividing $H$ by $H_{\max }$ (here $H_{\max }=\ln S$ ). Equitability assumes a value between 0 and 1 with 1 being complete evenness.

3.2. Diversity Richness or Species Richness. It is the simplest measure of biodiversity and is simply a count of the number of different species in a given area. Species richness is also referred to as alpha diversity. Species richness is commonly used, along with other factors, as a measure for determining the overall health of different biological ecosystems. High species richness for a given area indicates a high level of ecosystem stability, thus allowing the ecosystem to better withstand natural or anthropogenic disturbance.

Richness $R$ simply quantifies how many different types the dataset of interest contains. For example, species richness (usually notated $S$ ) of a dataset is the number of different species in the corresponding species list. Richness is a simple measure, so it has been a popular diversity index in ecology, where abundance data are often not available for the datasets of interest. However, if true diversity is calculated with $q=0$, the effective number of types $\left({ }^{0} D\right)$ equals the actual number of types $(R)$.

3.3. Species Evenness. It refers to how each species is close in numbers in an environment. Mathematically it is defined as a diversity index, a measure of biodiversity which quantifies how the community is equal numerically. The evenness of a community can be represented by Pielou's evenness index:

$$
J^{\prime}=\frac{H^{\prime}}{H_{\max }^{\prime}},
$$

where $H^{\prime}$ is the number derived from the Shannon diversity index and $H_{\max }^{\prime}$ is the maximum value of $H^{\prime}$, equal to

$$
H_{\max }^{\prime}=-\sum_{i=1}^{S} \frac{1}{S} \ln \frac{1}{S}=\ln S .
$$

$J^{\prime}$ is constrained between 0 and 1 . The less the variation in communities between the species is, the higher $J^{\prime}$ is. Other indices have been proposed by authors where $H_{\min }^{\prime}>0$, for example, Hurlburt's evenness index. $S$ is the total number of species.

3.4. Biodiversity Dominance or Simpson's Dominance Index. It measures biodiversity based on the probability that two individuals randomly selected from a sample will belong to the same species (or some category other than species). Simpson's dominance index ranges from 0 (all taxa are equally present) to 1.0 (one taxon dominates the community completely). Statistical analyses for diversity index, diversity richness, evenness, and biodiversity dominance were carried out to count the biodiversity criteria.

\section{Results}

The results of the biodiversity of fish and shellfish resources of the selected estuaries are presented (Table 1). The aspects presented include the species composition, biodiversity index, species richness, species evenness, and species dominance. The occurrence of finfish and shellfishes in Kadinamkulam backwaters on a percentage basis in relation to different months and its correlation significance with various environmental parameters are presented in Tables 2, 5, 6, and 7. A total of thirty species of fin and shellfishes were recorded from Kadinamkulam backwater. The finfish Oreochromis mossambicus ranged from $1.81 \%$ in August to $50.5 \%$ in June. A significant negative correlation was noted between the number of fishes and silicate-silicon level.

The highest percentage of Etroplus suratensis was recorded in January (38.32\%) and the lowest (1.04\%) was obtained in August. No significant correlation however was noted with any of the environmental parameters. The percentage of E. maculatus ranged from $0.13 \%$ in March to $5.05 \%$ in June. The occurrence of this species showed highly significant negative correlation with temperature and significant negative correlation with phosphate phosphorus. The occurrence of Terapon jarbua ranged from $0.15 \%$ in March to $0.82 \%$ in July and October. The occurrence showed a significant negative correlation with temperature, salinity and organic carbon. The percentage of Caranx sehfsciatis ranged from 0.10 in March to 3.95 in October. This species showed a significant positive correlation with DO and significant negative correlation with temperature, hydrogen sulfide, salinity, and organic carbon. The percentage of C. ignobilis varied from 0.15 in March to 8.29 in July. This species showed a significant positive correlation with DO and significant negative correlation with temperature and alkalinity. A highly significant negative correlation was noticed with organic carbon. 
TABLE 1: Species composition of selected backwaters.

\begin{tabular}{|c|c|c|c|}
\hline Sl. no. & Order & Family & Species \\
\hline 1 & Elopiformes & Elopidae & Elops machnata (Forsskål) \\
\hline 2 & Elopiformes & Megalopidae & Megalops cyprinoides (Broussonet) \\
\hline 3 & Elopiformes & Tachysuridae & Tachysurus subrostratus (Valenciennes) \\
\hline 4 & Siluriformes & Bagridae & Mystus gulio (Hamilton) \\
\hline 5 & Siluriformes & Hemiramphidae & Hyphorhampus improvis (Valenciennes) \\
\hline 6 & Siluriformes & Mugilidae & Mugil cephalus (Linnaeus) \\
\hline 7 & Siluriformes & Mugilidae & Liza parsia (Hamilton-Buchanan) \\
\hline 8 & Siluriformes & Mugilidae & Valamugil cunnesius (Valenciennes) \\
\hline 9 & Siluriformes & Terapontidae & Terapon jarbua (Forsskål) \\
\hline 10 & Siluriformes & Carangidae & Caranx ignobilis (Forsskål) \\
\hline 11 & Siluriformes & Carangidae & Caranx sehfsciatis (Bloch) \\
\hline 12 & Siluriformes & Lutjanidae & Lutjanus johnii (Bloch) \\
\hline 13 & Siluriformes & Gerreidae & Gerres filamentosus (Cuvier) \\
\hline 14 & Perciformes & Cichlidae & Oreochromis mossambicus (Peters) \\
\hline 15 & Perciformes & Cichlidae & Etroplus suratensis (Bloch) \\
\hline 16 & Perciformes & Cichlidae & Etroplus maculatus (Bloch) \\
\hline 17 & Perciformes & Gobiidae & Glossogobius giuris (Hamilton-Buchanan) \\
\hline 18 & Perciformes & Anabantidae & Anabas testudineus (Bloch) \\
\hline 19 & Perciformes & Ambassidae & Chanda nama (Hamilton-Buchanan) \\
\hline 20 & Perciformes & Ambassidae & Chanda ranga (Hamilton-Buchanan) \\
\hline 21 & Cypriniformes & Anguillidae & Anguilla bengalensis (Gray) \\
\hline 22 & Cypriniformes & Cyprinidae & Catla catla (Hamilton-Buchanan) \\
\hline 23 & Cypriniformes & Cyprinidae & Puntius filamentosus (Valenciennes) \\
\hline 24 & Cypriniformes & Scatophagidae & Scatophagus argus (Bloch) \\
\hline 25 & Cypriniformes & Ariidae & Arius arius (Hamilton-Buchanan) \\
\hline 26 & Pleuronectiformes & Soleidae & Austroglossus pectoralis (Kaup) \\
\hline 27 & Decapoda & Palaemonidae & Macrobrachium rosenbergii (De Man) \\
\hline 28 & Decapoda & Palaemonidae & Macrobrachium idella (Heller) \\
\hline 29 & Decapoda & Penaeidae & Metapenaeus brevicornis (Milne Edwards) \\
\hline 30 & Decapoda & Penaeidae & Metapenaeus dobsoni (Miers) \\
\hline 31 & Decapoda & Penaeidae & Penaeus monodon (Fabricius) \\
\hline 32 & Decapoda & Penaeidae & Penaeus indicus (Milne Edwards) \\
\hline 33 & Decapoda & Portunidae & Scylla serrata (Forsskål) \\
\hline
\end{tabular}

The percentage of Chanda ranga ranged from 0.40 in July to 2.15 in May. This species showed significant negative correlation with salinity, significant positive correlation with $\mathrm{pH}$, copper, and zinc, and highly significant negative correlation with lead and manganese. The percentage of $C$. nama varied from 0.16 in February to 3.79 in June. It had a significant negative correlation between temperature and hydrogen sulfide. The percentage of Mugil cephalus varied from $0.41 \%$ in March to $8.19 \%$ in July. It had a significant positive correlation with zinc, significant negative correlation with lead and highly significant correlation with manganese. The percentage of Channa marulius varied from 0.10 in August to 2.56 in June. It showed a significant negative correlation with temperature. The percentage of $C$. striatus varied between 0.17 in August and 0.65 in July. It had a positive significant correlation with nitrite nitrogen and phosphate phosphorus.

The percentage of Megalops cyprinoides ranged between 0.28 in March and 6.87 in April. It showed a highly significant positive correlation with zinc and highly significant negative correlation with lead and manganese. The percentage of Gerres filamentosus ranged from 0.28 in March to 7.89 in October. It did not show any relationship with the environmental parameters. The percentage of Puntius filamentosus was 0.67 in December and 0.49 in November. The species was not observed during the rest of the months. It showed a highly significant positive correlation with alkalinity, significant positive correlation with organic carbon and copper, and significant negative correlation with silicate silicon. The percentage of Anabas testudineus ranged from 0.21 in February to 
TABLE 2: Biodiversity of finfish and shellfishes of Kadinamkulam backwater (\%).

\begin{tabular}{|c|c|c|c|c|c|c|c|c|c|c|c|c|}
\hline Name of fish & April & May & June & July & Aug. & Sep. & Oct. & Nov. & Dec. & Jan. & Feb. & Mar. \\
\hline Oreochromis mossambicus & 34.34 & 29.43 & 50.50 & 8.19 & 1.81 & 0.00 & 0.00 & 42.55 & 40.47 & 11.24 & 26.10 & 28.26 \\
\hline Etroplus suratensis & 28.62 & 30.66 & 12.29 & 11.13 & 1.04 & 2.62 & 3.88 & 5.00 & 3.04 & 38.32 & 5.22 & 2.77 \\
\hline Etroplus maculatus & 0.00 & 0.00 & 5.05 & 0.82 & 0.64 & 1.56 & 1.97 & 2.47 & 1.21 & 1.33 & 0.52 & 0.13 \\
\hline Terapon jarbua & 0.57 & 0.00 & 0.63 & 0.82 & 0.00 & 0.51 & 0.82 & 0.00 & 0.00 & 0.00 & 0.00 & 0.15 \\
\hline Caranx sehfsciatis & 1.72 & 0.00 & 3.79 & 3.24 & 1.82 & 2.82 & 3.95 & 0.00 & 0.00 & 0.00 & 0.42 & 0.10 \\
\hline Caranx ignobilis & 2.29 & 3.68 & 7.68 & 8.29 & 3.61 & 2.89 & 3.95 & 0.00 & 0.00 & 1.57 & 0.42 & 0.15 \\
\hline Chanda ranga & 0.97 & 2.15 & 0.63 & 0.40 & 0.00 & 0.87 & 0.90 & 0.84 & 0.66 & 0.00 & 0.00 & 0.00 \\
\hline Chanda nama & 0.00 & 0.00 & 3.79 & 0.40 & 0.00 & 1.78 & 2.18 & 3.34 & 0.56 & 0.26 & 0.16 & 0.21 \\
\hline Mugil cephalus & 11.45 & 14.71 & 2.56 & 8.19 & 1.81 & 3.61 & 7.89 & 5.19 & 4.88 & 0.00 & 1.04 & 0.41 \\
\hline Channa marulius & 0.00 & 0.00 & 2.56 & 0.16 & 0.10 & 0.00 & 0.00 & 1.01 & 0.32 & 1.53 & 0.52 & 0.36 \\
\hline Channa striatus & 0.00 & 0.00 & 0.00 & 0.65 & 0.17 & 0.51 & 0.00 & 0.57 & 0.22 & 0.00 & 0.00 & 0.00 \\
\hline Megalops cyprinoides & 6.87 & 4.29 & 1.89 & 1.01 & 0.31 & 2.11 & 3.95 & 1.31 & 1.67 & 1.55 & 0.63 & 0.28 \\
\hline Gerres filamentosus & 0.00 & 0.00 & 1.89 & 2.48 & 0.00 & 5.66 & 7.89 & 2.47 & 3.54 & 3.07 & 0.42 & 0.28 \\
\hline Puntius filamentosus & 0.00 & 0.00 & 0.00 & 0.00 & 0.00 & 0.00 & 0.00 & 0.49 & 0.67 & 0.00 & 0.00 & 0.00 \\
\hline Anabas testudineus & 1.14 & 2.45 & 2.56 & 0.49 & 0.00 & 0.00 & 0.00 & 0.00 & 0.73 & 1.02 & 0.21 & 0.31 \\
\hline Mystus gulio & 5.72 & 3.07 & 0.50 & 1.62 & 0.00 & 0.00 & 0.00 & 0.61 & 0.56 & 1.59 & 0.15 & 0.07 \\
\hline Arius arius & 0.00 & 0.00 & 0.76 & 0.82 & 0.00 & 0.00 & 0.00 & 0.00 & 0.00 & 1.61 & 0.21 & 0.07 \\
\hline Tachysurus subrostratus & 0.00 & 0.00 & 0.00 & 0.00 & 0.00 & 0.00 & 0.20 & 0.00 & 0.26 & 0.00 & 0.00 & 0.00 \\
\hline Valamugil cunnesius & 5.72 & 6.13 & 1.28 & 1.66 & 0.00 & 8.71 & 7.87 & 2.85 & 2.25 & 0.00 & 0.00 & 0.00 \\
\hline Liza parsia & 0.00 & 0.00 & 0.38 & 0.00 & 0.00 & 7.84 & 7.89 & 2.55 & 2.67 & 0.00 & 0.21 & 0.13 \\
\hline Elops machnata & 0.00 & 0.00 & 0.00 & 0.00 & 0.00 & 0.56 & 0.00 & 0.00 & 0.32 & 0.00 & 0.00 & 0.28 \\
\hline Hyphorhampus improvis & 0.00 & 0.00 & 0.50 & 0.32 & 0.00 & 2.71 & 0.82 & 0.87 & 0.30 & 0.00 & 0.00 & 0.00 \\
\hline Periophthalmus weberi & 0.00 & 0.00 & 0.50 & 0.16 & 0.18 & 0.33 & 0.40 & 0.20 & 0.00 & 0.00 & 0.00 & 0.00 \\
\hline Glossogobius giuris & 0.00 & 0.00 & 0.00 & 0.00 & 0.00 & 0.87 & 0.40 & 0.09 & 0.36 & 0.00 & 0.00 & 0.00 \\
\hline Anguilla bengalensis & 0.00 & 0.00 & 0.00 & 0.00 & 0.00 & 0.53 & 0.40 & 0.61 & 0.79 & 0.00 & 0.00 & 0.00 \\
\hline Scylla serrata & 0.57 & 0.67 & 0.26 & 0.08 & 0.18 & 0.20 & 0.19 & 0.15 & 0.10 & 0.05 & 0.03 & 0.26 \\
\hline Penaeus monodon & 0.00 & 0.00 & 0.00 & 0.00 & 0.16 & 0.03 & 0.03 & 0.09 & 0.02 & 0.05 & 0.05 & 0.00 \\
\hline Penaeus indicus & 0.00 & 2.76 & 0.00 & 49.06 & 88.19 & 48.15 & 38.84 & 25.73 & 34.40 & 36.79 & 63.69 & 65.77 \\
\hline Metapenaeus brevicornis & 0.00 & 0.00 & 0.00 & 0.00 & 0.00 & 2.56 & 3.67 & 0.49 & 0.00 & 0.00 & 0.00 & 0.00 \\
\hline Metapenaeus dobsoni & 0.00 & 0.00 & 0.00 & 0.00 & 0.00 & 2.56 & 1.89 & 0.49 & 0.00 & 0.00 & 0.00 & 0.00 \\
\hline
\end{tabular}

2.56 in July. There exists no relationship with the environmental parameters. The percentage of Mystus gulio ranged from 0.07 in March to 5.72 in April. It showed a significant positive correlation with zinc and significant negative correlation with lead and manganese. The percentage of Arius arius varied from 0.07 in March to 1.61 in January. It showed a significant negative correlation with copper. The percentage of Tachysurus subrostratus was 0.2 in October and 0.26 in December. This species was not observed in other months. It had a significant positive correlation with nitrite nitrogen and copper.

The percentage of Valamugil cunnesius varied from 1.28 in June to 7.87 in October. It had a positive significant correlation with copper, negative significant correlation with hydrogen sulfide, lead, nickel, and zinc, and highly significant negative correlation with salinity and ammonia nitrogen. The percentage of Liza parsia ranged between 0.13 in March and 7.89 in October. It had a significant positive correlation with alkalinity and copper and negative significant correlation with salinity, ammonia nitrogen, and nickel. The percentage of Elops machnata ranged from 0.28 in March to 0.56 in September. The occurrence did not exhibit any definite relationship with the environmental parameters. The percentage of Hyphorhampus improvis ranged from 0.30 in December to 2.71 in September. It showed a significant positive correlation with DO and significant negative correlation with salinity, hydrogen sulfide, and nickel. The percentage of Periophthalmus weberi ranged from 0.16 in July to 0.5 in June. It showed a significant positive correlation with DO and significant negative correlation with temperature, salinity, phosphate phosphorus, hydrogen sulfide, and nickel. The percentage of Glossogobius giuris ranged from 0.09 in November to 0.87 in September. It showed a significant positive correlation with DO and copper and significant negative correlation with ammonia nitrogen and nickel. The percentage of Anguilla bengalensis ranged from 0.40 in October to 0.79 in December. 
TABLE 3: Biodiversity of finfish and shellfishes of Veli Lake (\%).

\begin{tabular}{|c|c|c|c|c|c|c|c|c|c|c|c|c|}
\hline Name of fish & April & May & June & July & Aug. & Sept. & Oct. & Nov. & Dec. & Jan. & Feb. & Mar. \\
\hline Oreochromis mossambicus & 51.02 & 73.07 & 81.33 & 78.67 & 57.42 & 74.96 & 88.54 & 53.37 & 43.70 & 32.38 & 35.66 & 38.13 \\
\hline Etroplus suratensis & 1.13 & 2.48 & 2.35 & 0.79 & 0.29 & 5.32 & 1.78 & 1.50 & 2.51 & 5.94 & 3.11 & 0.02 \\
\hline Etroplus maculatus & 22.68 & 18.58 & 2.09 & 0.89 & 0.00 & 0.00 & 0.00 & 3.25 & 8.90 & 0.00 & 0.00 & 0.00 \\
\hline Terapon jarbua & 0.57 & 0.00 & 0.00 & 0.10 & 0.00 & 0.00 & 0.00 & 1.95 & 1.62 & 0.00 & 0.00 & 0.30 \\
\hline Caranx sehfsciatis & 0.57 & 0.00 & 0.26 & 0.48 & 2.79 & 1.24 & 0.90 & 3.25 & 3.56 & 0.00 & 1.20 & 0.45 \\
\hline Caranx ignobilis & 0.23 & 0.00 & 0.26 & 0.39 & 11.48 & 3.22 & 0.90 & 2.60 & 5.67 & 0.78 & 0.10 & 0.40 \\
\hline Chanda ranga & 0.57 & 0.00 & 0.00 & 0.79 & 2.87 & 0.52 & 0.00 & 0.00 & 0.00 & 0.00 & 0.51 & 0.05 \\
\hline Chanda nama & 0.34 & 0.62 & 3.65 & 0.00 & 2.87 & 0.55 & 0.00 & 0.00 & 0.00 & 0.00 & 2.26 & 0.20 \\
\hline Mugil cephalus & 1.13 & 1.24 & 4.17 & 0.31 & 0.00 & 0.00 & 0.36 & 13.02 & 17.72 & 3.46 & 1.02 & 0.45 \\
\hline Channa marulius & 0.00 & 0.00 & 0.00 & 7.73 & 0.00 & 2.06 & 0.99 & 0.65 & 0.81 & 0.00 & 0.51 & 0.20 \\
\hline Channa striatus & 0.00 & 0.00 & 0.00 & 4.03 & 0.00 & 1.50 & 0.00 & 0.91 & 2.43 & 0.00 & 0.51 & 0.50 \\
\hline Megalops cyprinoides & 0.57 & 0.00 & 0.36 & 0.79 & 0.00 & 0.00 & 0.79 & 1.30 & 2.91 & 6.95 & 2.09 & 0.50 \\
\hline Gerres filamentosus & 0.57 & 1.24 & 0.00 & 0.31 & 0.29 & 0.55 & 0.00 & 0.00 & 0.00 & 0.00 & 0.00 & 0.10 \\
\hline Puntius filamentosus & 0.00 & 0.00 & 0.26 & 0.15 & 0.00 & 0.78 & 0.45 & 0.33 & 0.00 & 0.00 & 0.00 & 0.00 \\
\hline Anabas testudineus & 0.00 & 2.48 & 4.69 & 3.92 & 1.15 & 2.50 & 0.00 & 3.25 & 2.43 & 2.51 & 1.02 & 0.00 \\
\hline Mystus gulio & 0.00 & 0.00 & 0.52 & 0.00 & 0.00 & 0.00 & 0.00 & 0.00 & 1.26 & 0.00 & 0.51 & 1.00 \\
\hline Arius arius & 0.00 & 0.19 & 0.00 & 0.00 & 0.00 & 0.00 & 0.30 & 0.00 & 0.00 & 0.45 & 0.51 & 0.15 \\
\hline Tachysurus subrostratus & 0.00 & 0.00 & 0.00 & 0.00 & 0.10 & 0.00 & 0.00 & 0.65 & 0.81 & 0.00 & 0.00 & 0.00 \\
\hline Valamugil cunnesius & 0.00 & 0.00 & 0.00 & 0.20 & 0.10 & 0.52 & 0.17 & 0.65 & 0.81 & 0.00 & 0.00 & 0.05 \\
\hline Liza parsia & 0.00 & 0.00 & 0.00 & 0.00 & 0.00 & 0.00 & 0.00 & 0.00 & 1.62 & 0.56 & 0.00 & 0.10 \\
\hline Elops machnata & 0.00 & 0.00 & 0.00 & 0.00 & 0.07 & 0.89 & 0.00 & 0.00 & 0.00 & 0.00 & 0.00 & 0.15 \\
\hline Hyphorhampus improvis & 0.00 & 0.00 & 0.00 & 0.00 & 0.00 & 0.00 & 0.00 & 0.65 & 0.81 & 0.00 & 0.00 & 0.00 \\
\hline Periophthalmus weberi & 0.00 & 0.00 & 0.00 & 0.25 & 0.21 & 0.00 & 0.78 & 0.59 & 0.40 & 0.00 & 0.00 & 0.00 \\
\hline Glossogobius giuris & 0.00 & 0.00 & 0.00 & 0.00 & 0.13 & 0.00 & 0.00 & 0.00 & 0.00 & 0.00 & 0.00 & 0.00 \\
\hline Anguilla bengalensis & 0.00 & 0.00 & 0.00 & 0.00 & 1.04 & 0.00 & 0.00 & 0.20 & 0.16 & 0.00 & 0.00 & 0.00 \\
\hline Austroglossus pectoralis & 0.00 & 0.00 & 0.00 & 0.03 & 0.00 & 0.02 & 0.05 & 0.03 & 0.16 & 0.00 & 0.00 & 0.00 \\
\hline Metapenaeus brevicornis & 0.00 & 0.00 & 0.00 & 0.00 & 0.00 & 2.00 & 0.50 & 1.63 & 0.16 & 0.00 & 0.00 & 0.00 \\
\hline Macrobrachium idella & 0.00 & 0.00 & 0.00 & 0.00 & 10.44 & 2.08 & 1.07 & 3.25 & 1.21 & 0.00 & 0.00 & 0.00 \\
\hline Scylla serrata & 0.23 & 0.12 & 0.05 & 0.16 & 0.13 & 0.65 & 0.45 & 0.13 & 0.24 & 0.08 & 0.00 & 0.05 \\
\hline Penaeus monodon & 0.00 & 0.00 & 0.00 & 0.00 & 0.00 & 0.00 & 0.00 & 0.33 & 0.08 & 0.00 & 0.06 & 0.00 \\
\hline Penaeus indicus & 20.41 & 0 & 0 & 0 & 8.61 & 0.65 & 1.99 & 6.51 & 0 & 46.90 & 50.94 & 57.19 \\
\hline
\end{tabular}

It showed a significant positive correlation with organic carbon and highly significant positive correlation with alkalinity and copper.

The percentage of Scylla serrata ranged between 0.03 in February to 0.67 in May. It showed a significant positive correlation with $\mathrm{pH}$, silicate silicon, total nitrogen, and zinc and highly significant negative correlation with lead and manganese. The percentage of Penaeus monodon ranged from 0.02 in December to 0.16 in August. It did not show any correlation significance. The percentage of $P$. indicus varied from 2.76 in May to 88.19 in August. It had a significant positive relationship with lead and highly significant positive relationship with manganese. The percentage of Metapenaeus brevicornis ranged between 0.49 in November to 3.67 in October. It showed a significant positive correlation with copper and significant negative correlation with salinity, ammonia nitrogen, and nickel. The percentage of $M$. dobsoni ranged from 0.49 in November to 2.56 in September. It showed a significant negative correlation with salinity, ammonia nitrogen, and nickel.

In Veli Lake, a total of thirty-one species were recorded from the present study. The monthly occurrence of each species in percentage and their correlation significance are presented in Tables 3, 8, 9, and 10. The percentage of Oreochromis mossambicus ranged between 32.38 in January and 88.54 in October. It showed a significant negative correlation with hydrogen sulfide and highly significant positive correlation with organic carbon and sediment phosphorus. The percentage of Etroplus suratensis varied from 0.02 in March to 5.94 in January. This species never showed any significance with any environmental parameters. The percentage of $E$. maculatus varied from 0.89 in July to 22.68 in April. The occurrence of this species showed significant positive correlation with temperature, $\mathrm{pH}$, ammonia nitrogen, and nickel, 
TABLE 4: Biodiversity of finfish and shellfish of Poonthura backwater (\%).

\begin{tabular}{|c|c|c|c|c|c|c|c|c|c|c|c|c|}
\hline Name of fish & April & May & June & July & Aug. & Sept. & Oct. & Nov. & Dec. & Jan. & Feb. & Mar. \\
\hline Oreochromis mossambicus & 25.33 & 35.30 & 39.79 & 55.59 & 46.72 & 65.92 & 55.46 & 46.40 & 27.97 & 32.62 & 23.18 & 26.12 \\
\hline Etroplus suratensis & 15.20 & 13.11 & 10.47 & 2.01 & 9.45 & 6.60 & 5.42 & 7.87 & 16.47 & 21.05 & 9.66 & 11.05 \\
\hline Etroplus maculatus & 5.07 & 4.54 & 5.24 & 5.53 & 0.09 & 0.00 & 0.00 & 4.36 & 6.97 & 0.00 & 0.00 & 0.00 \\
\hline Terapon jarbua & 4.56 & 1.58 & 0.00 & 0.00 & 0.48 & 0.00 & 2.64 & 3.65 & 2.22 & 1.65 & 1.30 & 0.00 \\
\hline Caranx sehfsciatis & 0.00 & 0.00 & 0.00 & 0.65 & 0.00 & 2.69 & 3.63 & 1.33 & 1.14 & 1.28 & 0.48 & 0.00 \\
\hline Caranx ignobilis & 0.00 & 0.00 & 0.00 & 0.65 & 4.77 & 6.10 & 3.94 & 4.69 & 8.25 & 1.14 & 0.51 & 0.00 \\
\hline Chanda ranga & 0.00 & 0.00 & 0.00 & 0.55 & 4.27 & 6.60 & 6.39 & 2.30 & 3.40 & 0.00 & 0.00 & 0.00 \\
\hline Chanda nama & 10.13 & 5.35 & 0.00 & 0.00 & 0.00 & 2.34 & 2.66 & 4.69 & 5.09 & 11.21 & 14.63 & 0.00 \\
\hline Mugil cephalus & 10.72 & 6.33 & 7.85 & 0.65 & 2.37 & 0.00 & 1.92 & 8.73 & 4.80 & 0.00 & 5.02 & 0.00 \\
\hline Channa marulius & 5.86 & 5.78 & 5.24 & 1.94 & 0.48 & 1.32 & 0.68 & 1.82 & 1.03 & 5.47 & 2.24 & 4.02 \\
\hline Channa striatus & 0.05 & 0.00 & 2.09 & 0.76 & 0.58 & 0.50 & 0.74 & 1.33 & 1.60 & 0.00 & 0.00 & 2.01 \\
\hline Megalops cyprinoides & 5.45 & 2.52 & 1.05 & 1.39 & 0.00 & 2.64 & 1.23 & 0.89 & 1.29 & 0.00 & 2.41 & 3.01 \\
\hline Gerres filamentosus & 1.52 & 0.00 & 5.76 & 0.74 & 2.37 & 0.00 & 1.25 & 0.56 & 0.00 & 0.00 & 0.00 & 0.00 \\
\hline Puntius filamentosus & 2.03 & 3.03 & 0.00 & 0.00 & 0.00 & 0.00 & 0.90 & 1.63 & 1.98 & 10.68 & 4.83 & 1.00 \\
\hline Anabas testudineus & 2.03 & 0.00 & 0.00 & 0.00 & 0.00 & 0.66 & 1.00 & 0.00 & 0.00 & 0.00 & 0.00 & 0.00 \\
\hline Mystus gulio & 1.52 & 0.58 & 0.00 & 0.00 & 0.00 & 0.00 & 0.22 & 0.10 & 0.00 & 0.00 & 0.48 & 0.00 \\
\hline Arius arius & 0.71 & 0.35 & 0.00 & 0.28 & 0.00 & 0.00 & 0.00 & 0.00 & 0.11 & 0.00 & 0.29 & 0.00 \\
\hline Valamugil cunnesius & 5.50 & 0.00 & 5.24 & 1.39 & 0.23 & 4.35 & 4.32 & 1.90 & 2.85 & 0.00 & 0.48 & 0.00 \\
\hline Liza parsia & 0.00 & 2.54 & 0.00 & 0.00 & 2.03 & 0.00 & 2.10 & 2.62 & 1.79 & 0.00 & 0.00 & 0.00 \\
\hline Elops machnata & 2.82 & 1.23 & 0.00 & 0.00 & 0.23 & 0.00 & 0.90 & 0.00 & 0.66 & 0.00 & 0.50 & 0.50 \\
\hline Catla catla & 0.00 & 0.10 & 0.31 & 0.00 & 0.00 & 0.00 & 0.08 & 0.06 & 0.00 & 0.06 & 0.05 & 0.05 \\
\hline Hyphorhampus improvis & 0.00 & 0.00 & 0.00 & 0.00 & 1.32 & 0.00 & 0.51 & 0.00 & 3.17 & 4.29 & 0.00 & 0.00 \\
\hline Periophthalmus weberi & 0.00 & 0.00 & 0.00 & 0.70 & 0.48 & 0.00 & 0.88 & 1.21 & 0.58 & 0.00 & 0.00 & 0.00 \\
\hline Gaterius diagramms & 0.00 & 0.00 & 0.00 & 0.10 & 0.00 & 0.26 & 0.43 & 0.06 & 0.00 & 0.00 & 0.00 & 0.00 \\
\hline Scatophagus argus & 0.00 & 0.00 & 0.00 & 0.09 & 0.00 & 0.00 & 0.00 & 0.25 & 0.69 & 0.00 & 0.00 & 0.00 \\
\hline Lutjanus johnii & 0.00 & 0.00 & 0.00 & 0.00 & 0.03 & 0.00 & 0.00 & 0.00 & 0.00 & 0.00 & 0.00 & 0.00 \\
\hline Scomberomorus guttatus & 0.00 & 0.00 & 0.00 & 0.23 & 0.00 & 0.00 & 0.83 & 0.34 & 0.00 & 0.00 & 0.00 & 0.00 \\
\hline Scylla serrata & 1.52 & 0.50 & 0.21 & 0.17 & 0.00 & 0.00 & 1.07 & 1.09 & 2.27 & 0.02 & 0.08 & 1.00 \\
\hline Penaeus monodon & 0.00 & 0.00 & 0.00 & 0.00 & 0.00 & 0.00 & 0.00 & 0.05 & 0.05 & 0.00 & 0.05 & 0.00 \\
\hline Penaeus indicus & 0.00 & 14.62 & 13.09 & 25.16 & 23.87 & 0.00 & 0.00 & 1.58 & 3.69 & 10.52 & 33.80 & 51.23 \\
\hline Macrobrachium idella & 0.00 & 2.52 & 3.66 & 1.61 & 0.00 & 0.00 & 1.64 & 0.00 & 1.58 & 0.00 & 0.00 & 0.00 \\
\hline
\end{tabular}

highly significant positive correlation with nitrite nitrogen, silicate silicon, and zinc, and highly significant negative correlation with lead and manganese.

The percentage of Caranx sehfsciatis ranged from 0.26 in June to 1.95 in November. This species occurrence showed significant positive correlation with copper and negative significance with ammonia nitrogen and phosphate phosphorus. The percentage of $C$. ignobilis varied from 0.10 in February to 11.48 in August. It showed significant negative correlation with ammonia nitrogen, phosphate phosphorus, and nickel. The percentage of Chanda ranga ranged from 0.05 in March to 2.87 in August. There was no significance with any of the environmental parameters to this species. The percentage of C. nama ranged between 0.20 in March and 3.65 in June. No significance was with environmental parameters. The percentage of Mugil cephalus ranged from 0.31 in July to 17.72 in December. This species showed significant negative correlation with alkalinity and organic carbon. The percentage of Channa marulius varied between 0.20 in March and 7.73 in July. It showed a significant positive correlation with DO and total nitrogen. The percentage of C. striatus ranged between 0.50 in March and 4.03 in July. It showed a positive significance with salinity and DO and negative significance with zinc.

The percentage of Megalops cyprinoides ranged from 0.36 in June to 6.95 in January. Its occurrence showed significant negative correlation with DO. The percentage of Gerres filamentosus ranged between 0.10 in March and 1.24 in May. It showed significant positive correlation with temperature, $\mathrm{pH}$, and organic carbon and negative correlation with manganese and highly significant positive correlation with nitrite nitrogen and silicate silicon. The percentage of Puntius filamentosus ranged between 0.15 in July and 0.78 in September. It showed significant negative correlation with $\mathrm{pH}$, hydrogen 
TABLE 5: Karl Pearson correlation showing the significance (5\%) by relating the number of fishes and physicochemical parameters of Kadinamkulam backwater.

\begin{tabular}{|c|c|c|c|c|c|}
\hline Name of fish & Temperature & $\mathrm{pH}$ & Salinity & Alkalinity & Dissolved oxygen \\
\hline Oreochromis mossambicus & -0.12 & 0.42 & 0.17 & 0.14 & -0.37 \\
\hline Etroplus suratensis & 0.04 & 0.17 & 0.34 & -0.28 & -0.28 \\
\hline Etroplus maculatus & $-0.74^{* *}$ & -0.04 & -0.21 & 0.06 & 0.42 \\
\hline Terapon jarbua & $-0.58^{*}$ & -0.46 & $-0.65^{*}$ & -0.31 & 0.48 \\
\hline Caranx sehfsciatis & $-0.63^{*}$ & -0.41 & $-0.62^{*}$ & -0.35 & $0.63^{*}$ \\
\hline Caranx ignobilus & $-0.67^{*}$ & -0.20 & -0.40 & $-0.61^{*}$ & $0.65^{*}$ \\
\hline Chanda ranga & -0.01 & $0.60^{*}$ & $-0.53^{*}$ & 0.29 & 0.06 \\
\hline Chanda nama & $-0.57^{*}$ & 0.10 & -0.47 & 0.35 & 0.37 \\
\hline Mugil cephalus & -0.03 & 0.48 & -0.46 & 0.09 & -0.04 \\
\hline Channa marulius & $-0.51^{*}$ & -0.02 & 0.25 & -0.18 & 0.09 \\
\hline Channa striatus & -0.35 & -0.06 & -0.31 & 0.38 & $0.65^{*}$ \\
\hline Megalops cyprinoides & 0.04 & 0.26 & -0.34 & 0.05 & -0.29 \\
\hline Gerrus filamentosus & $-0.49^{*}$ & -0.42 & -0.30 & 0.45 & 0.49 \\
\hline Puntius filamentosus & -0.18 & 0.32 & 0.27 & $0.75^{* *}$ & -0.08 \\
\hline Anabas testudineus & -0.26 & 0.32 & 0.07 & -0.47 & -0.06 \\
\hline Mystus gulio & 0.15 & 0.32 & 0.01 & -0.21 & -0.40 \\
\hline Arius arius & -0.45 & -0.38 & 0.46 & -0.41 & 0.21 \\
\hline Tachysurus subostratus & -0.28 & -0.10 & 0.16 & 0.45 & -0.04 \\
\hline Valamugil cunnaecius & -0.03 & 0.06 & $-0.70^{* *}$ & 0.36 & 0.25 \\
\hline Liza parsia & -0.19 & -0.26 & $-0.52^{*}$ & $0.55^{*}$ & 0.41 \\
\hline Elops machnata & 0.11 & -0.38 & -0.16 & 0.26 & 0.33 \\
\hline Hyphoramphus improvis & -0.23 & -0.27 & $-0.58^{*}$ & 0.38 & $0.66^{*}$ \\
\hline Periophthalmus weberi & $-0.63^{*}$ & -0.16 & $-0.63^{*}$ & -0.01 & $0.63^{*}$ \\
\hline Glossogobius giuris & -0.14 & -0.34 & -0.38 & 0.45 & $0.51^{*}$ \\
\hline Anguilla bengalensis & -0.22 & 0.07 & -0.10 & $0.87^{* *}$ & 0.22 \\
\hline Scylla serrata & 0.40 & $0.59^{*}$ & -0.43 & -0.17 & -0.36 \\
\hline Penaeus monodon & 0.17 & 0.23 & 0.22 & 0.29 & 0.03 \\
\hline Penaeus indicus & 0.26 & -0.43 & 0.21 & -0.04 & 0.15 \\
\hline Metapenaeus brevicornis & -0.14 & -0.29 & $-0.59^{*}$ & 0.38 & 0.34 \\
\hline Metapenaeus dobsoni & -0.10 & -0.31 & $-0.61^{*}$ & 0.40 & 0.48 \\
\hline
\end{tabular}

${ }^{*}$ Significant, ${ }^{* *}$ highly significant.

sulfide, ammonia nitrogen, and phosphate phosphorus and significant positive correlation with organic carbon. The percentage of Anabas testudineus ranged between 1.02 in February and 3.92 in July. It showed significant negative correlation with temperature and alkalinity and positive significance with salinity and dissolved oxygen. The percentage of Mystus gulio ranged from 0.51 in February to 1.26 in December. It showed significant positive correlation with hydrogen sulfide, and phosphate phosphorus and negative significance with organic carbon.

The percentage of Arius arius ranged from 0.15 in March to 0.45 in January. It showed positive significance with hydrogen sulfide and phosphate phosphorus. A highly significant negative correlation was observed with DO. The percentage of Tachysurus subrostratus was 0.1 in August, 0.65 in November, and 0.81 in December. This species was not noticed in other months. It showed a positive significance with salinity and copper and a negative significance with alkalinity and organic carbon. The percentage of Valamugil cunnesius ranged from 0.05 in March to 0.81 in December. It showed negative significance with $\mathrm{pH}$, ammonia nitrogen, and phosphate phosphorus. A positive significance was observed with copper. The percentage of Liza parsia was 0.1 in March, 0.56 in January, and 1.62 in December. The rest of the months never reported this species. There was no significance with environmental parameters. The percentage of Elops machnata was 0.07 in August, 0.15 in March, and 0.89 in September. The rest of the months never reported this species. It never showed significance with environmental parameters. The percentage of Hyporhamphus improvisus was 0.65 in November and 0.81 in December. The rest of the months never reported this species. It showed positive significance with salinity and copper. A negative significance was noticed with alkalinity and organic carbon. 
TABLE 6: Karl Pearson correlation showing the significance (5\%) by relating the number of fishes and nutrients of Kadinamkulam backwater.

\begin{tabular}{|c|c|c|c|c|c|}
\hline Name of fish & Hydrogen sulfide & Ammonia nitrogen & Nitrite nitrogen & Phosphate phosphorus & Silicate silicon \\
\hline Oreochromis mossambicus & 0.18 & 0.41 & -0.21 & 0.13 & $-0.51^{*}$ \\
\hline Etroplus suratensis & 0.21 & 0.07 & 0.09 & 0.06 & 0.16 \\
\hline Etroplus maculatus & -0.42 & -0.06 & -0.12 & $-0.54^{*}$ & -0.49 \\
\hline Terapon jarbua & -0.36 & -0.07 & 0.02 & -0.08 & -0.13 \\
\hline Caranx sehfsciatis & $-0.53^{*}$ & -0.27 & -0.09 & -0.31 & 0.00 \\
\hline Caranx ignobilis & -0.47 & 0.05 & -0.38 & -0.35 & -0.08 \\
\hline Chanda ranga & -0.47 & -0.47 & -0.17 & -0.10 & 0.20 \\
\hline Chanda nama & $-0.51^{*}$ & -0.13 & -0.11 & -0.46 & -0.49 \\
\hline Mugil cephalus & -0.40 & -0.20 & -0.12 & 0.05 & 0.15 \\
\hline Channa marulius & 0.04 & 0.28 & -0.10 & -0.30 & -0.49 \\
\hline Channa striatus & $-0.58^{*}$ & 0.23 & -0.47 & $-0.54^{*}$ & -0.41 \\
\hline Megalops cyprinoides & -0.19 & -0.43 & 0.19 & 0.19 & 0.33 \\
\hline Gerres filamentosus & -0.43 & -0.45 & 0.49 & -0.46 & -0.20 \\
\hline Puntius filamentosus & -0.22 & 0.14 & 0.02 & -0.34 & $-0.56^{*}$ \\
\hline Anabas testudineus & 0.04 & 0.03 & -0.26 & 0.00 & 0.03 \\
\hline Mystus gulio & 0.06 & 0.11 & -0.13 & 0.28 & 0.21 \\
\hline Arius arius & 0.18 & 0.39 & 0.10 & -0.27 & -0.31 \\
\hline Tachysurus subrostratus & -0.14 & -0.28 & $0.57^{*}$ & -0.17 & -0.23 \\
\hline Valamugil cunnesius & $-0.51^{*}$ & $-0.71^{* *}$ & 0.12 & -0.12 & 0.34 \\
\hline Liza parsia & -0.46 & $-0.66^{*}$ & 0.34 & -0.31 & 0.07 \\
\hline Elops machnata & 0.00 & -0.28 & -0.08 & -0.04 & 0.16 \\
\hline Hyphorhampus improvis & $-0.53^{*}$ & -0.48 & -0.15 & -0.43 & 0.07 \\
\hline Periophthalmus weberi & $-0.64^{*}$ & -0.36 & -0.14 & $-0.50^{*}$ & -0.16 \\
\hline Glossogobius giuris & -0.41 & $-0.62^{*}$ & 0.12 & -0.35 & 0.17 \\
\hline Anguilla bengalensis & -0.44 & -0.28 & 0.16 & -0.45 & -0.34 \\
\hline Scylla serrata & -0.04 & -0.33 & -0.27 & 0.40 & $0.55^{*}$ \\
\hline Penaeus monodon & -0.29 & -0.18 & -0.11 & -0.42 & 0.11 \\
\hline Penaeus indicus & 0.19 & 0.10 & 0.08 & 0.02 & 0.11 \\
\hline Metapenaeus brevicornis & -0.40 & $-0.68^{*}$ & 0.44 & -0.18 & 0.17 \\
\hline Metapenaeus dobsoni & -0.44 & $-0.67^{*}$ & 0.21 & -0.26 & 0.23 \\
\hline
\end{tabular}

${ }^{*}$ Significant, ${ }^{* *}$ highly significant.

The percentage of Periophthalmus weberi ranged from 0.21 in August to 0.59 in November. It showed a significant negative correlation with $\mathrm{pH}$ and phosphate phosphorus. The percentage of Glossogobius giuris was 0.13 in August and the rest of the months never reported this species. No significance was observed with any environmental parameters. The percentage of Anguilla bengalensis was 0.2 in November, 0.16 in December, and 1.04 in August. Rest of the months never reported this species. The percentage of Austroglossus pectoralis ranged from 0.02 in September to 0.16 in December. A negative significance of this species with $\mathrm{pH}$ was observed. The percentage of Metapenaeus brevicornis ranged from 0.16 in December to 2.0 in September. It showed negative significance with $\mathrm{pH}$, ammonia nitrogen, and phosphate phosphorus and positive significance with copper. The percentage of Macrobrachium idella ranged from 1.07 in October to 10.44 in August. It showed significant negative correlation with hydrogen sulfide, ammonia nitrogen, phosphate phosphorus, and nickel.
The percentage of Scylla serrata ranged from 0.05 in March to 0.65 in September. It showed positive significance with alkalinity, negative significance with hydrogen sulfide, ammonia nitrogen, and highly significant positive correlation with organic carbon. The percentage of Penaeus monodon was 0.06 in February, 0.08 in December, and 0.33 in November. The remaining months never reported this species. A negative significance was noted with alkalinity. The percentage of $P$. indicus ranged from 0.65 in August to 57.19 in March. It showed a negative significance with total nitrogen, highly significant negative correlation with $\mathrm{DO}$, and highly significant positive correlation with hydrogen sulfide, phosphate phosphorus, and total phosphorus.

The results of the biodiversity of fishes in percentage and their significance with environmental parameters of Poonthura backwater were presented in Tables 4, 11, 12, and 13. A total of thirty-one species were recorded from the Poonthura backwater. The percentage of Oreochromis mossambicus ranged from 23.18 in February to 65.92 in 
TABLE 7: Karl Pearson correlation showing the significance (5\%) by relating the number of fishes and sediment parameters of Kadinamkulam backwater.

\begin{tabular}{|c|c|c|c|c|c|c|c|c|}
\hline Name of fish & Organic carbon & Total phosphorous & Total nitrogen & Copper & Lead & Manganese & Nickel & Zinc \\
\hline Oreochromis mossambicus & 0.27 & 0.23 & 0.23 & -0.03 & -0.26 & -0.40 & 0.42 & 0.11 \\
\hline Etroplus suratensis & -0.13 & -0.10 & -0.10 & -0.36 & -0.21 & -0.34 & 0.34 & 0.33 \\
\hline Etroplus maculatus & -0.17 & -0.09 & -0.09 & 0.13 & -0.09 & -0.01 & -0.23 & -0.28 \\
\hline Terapon jarbua & $-0.56^{*}$ & 0.24 & 0.24 & -0.26 & 0.01 & 0.01 & -0.02 & -0.10 \\
\hline Caranx sehfsciatis & $-0.69^{*}$ & 0.00 & 0.00 & -0.13 & 0.01 & 0.09 & -0.30 & -0.21 \\
\hline Caranx ignobilis & $-0.83^{* *}$ & -0.18 & -0.18 & -0.37 & 0.11 & 0.06 & -0.14 & -0.38 \\
\hline Chanda ranga & 0.15 & 0.21 & 0.21 & $0.50^{*}$ & $-0.78^{* *}$ & $-0.79^{* *}$ & -0.42 & $0.52^{*}$ \\
\hline Chanda nama & 0.08 & 0.08 & 0.08 & 0.35 & -0.24 & -0.14 & -0.34 & -0.12 \\
\hline Mugil cephalus & -0.05 & 0.34 & 0.34 & 0.20 & $-0.64^{*}$ & $-0.72^{* *}$ & -0.12 & $0.53^{*}$ \\
\hline Channa marulius & -0.14 & -0.18 & -0.18 & -0.23 & 0.12 & 0.08 & 0.19 & -0.33 \\
\hline Channa striatus & 0.17 & -0.36 & -0.36 & 0.15 & 0.11 & 0.17 & -0.23 & -0.23 \\
\hline Megalops cyprinoides & -0.09 & 0.38 & 0.38 & 0.10 & $-0.77^{* *}$ & $-0.79^{* *}$ & 0.03 & $0.83^{* *}$ \\
\hline Gerres filamentosus & 0.18 & 0.12 & 0.12 & 0.46 & -0.01 & 0.22 & -0.48 & -0.08 \\
\hline Puntius filamentosus & $0.67^{*}$ & 0.06 & 0.06 & $0.54^{*}$ & -0.20 & -0.13 & -0.03 & 0.11 \\
\hline Anabas testudineus & -0.37 & -0.03 & -0.03 & -0.25 & -0.30 & -0.46 & 0.16 & 0.06 \\
\hline Mystus gulio & -0.17 & 0.13 & 0.13 & -0.35 & $-0.51^{*}$ & $-0.68^{*}$ & 0.46 & $0.68^{*}$ \\
\hline Arius arius & -0.30 & -0.33 & -0.33 & $-0.56^{*}$ & 0.47 & 0.40 & 0.34 & -0.44 \\
\hline Tachysurus subrostratus & 0.30 & 0.38 & 0.38 & $0.52^{*}$ & -0.11 & 0.03 & -0.19 & 0.07 \\
\hline Valamugil cunnesius & 0.10 & 0.18 & 0.18 & $0.50^{*}$ & $-0.60^{*}$ & -0.47 & $-0.53^{*}$ & $0.52^{*}$ \\
\hline Liza parsia & 0.27 & 0.12 & 0.12 & $0.63^{*}$ & -0.21 & 0.04 & $-0.64^{*}$ & 0.13 \\
\hline Elops machnata & 0.26 & -0.23 & -0.23 & 0.25 & 0.10 & 0.21 & -0.23 & -0.03 \\
\hline Hyphorhampus improvis & 0.14 & -0.29 & -0.29 & 0.40 & -0.15 & 0.04 & $-0.58^{*}$ & 0.03 \\
\hline Periophthalmus weberi & -0.39 & -0.06 & -0.06 & 0.22 & -0.12 & 0.02 & $-0.54^{*}$ & -0.24 \\
\hline Glossogobius giuris & 0.23 & -0.17 & -0.17 & $0.52^{*}$ & -0.15 & 0.07 & $-0.58^{*}$ & 0.12 \\
\hline Anguilla bengalensis & $0.65^{*}$ & 0.04 & 0.04 & $0.75^{* *}$ & -0.27 & -0.07 & -0.40 & 0.17 \\
\hline Scylla serrata & -0.18 & 0.26 & 0.26 & 0.07 & $-0.73^{* *}$ & $-0.84^{* *}$ & -0.03 & $0.66^{*}$ \\
\hline Penaeus monodon & 0.10 & -0.44 & -0.44 & 0.35 & 0.02 & 0.19 & -0.41 & -0.03 \\
\hline Penaeus indicus & 0.00 & -0.25 & -0.25 & -0.04 & $0.69^{*}$ & $0.78^{* *}$ & -0.12 & $-0.50^{*}$ \\
\hline Metapenaeus brevicornis & 0.10 & 0.24 & 0.24 & $0.52^{*}$ & -0.18 & 0.05 & $-0.61^{*}$ & 0.12 \\
\hline Metapenaeus dobsoni & 0.14 & -0.02 & -0.02 & 0.49 & -0.17 & 0.05 & $-0.64^{*}$ & 0.12 \\
\hline
\end{tabular}

${ }^{*}$ Significant, ${ }^{* *}$ highly significant.

September. This species showed a significant negative correlation with temperature, hydrogen sulfide, nitrite nitrogen, and nickel and highly significant positive correlation with total nitrogen. The percentage of Etroplus suratensis ranged from 2.01 in July to 21.05 in January. It showed a significant positive correlation with nitrite nitrogen and total phosphorus. The percentage of E. maculatus ranged from 0.09 in August to 6.97 in December. This species showed positive significance with salinity and negative significance with alkalinity and lead. The percentage of Terapon jarbua ranged between 0.48 in August and 4.56 in April. It showed a highly significant negative correlation with lead and manganese and highly significant positive correlation with zinc.

The percentage of Caranx sehfsciatis ranged from 0.48 in February to 3.63 in October. It showed a negative significance with hydrogen sulfide, positive significance with zinc, highly significant positive correlation with organic carbon, and highly significant negative correlation with total phosphorus. The percentage of $C$. ignobilis ranged from 0.51 in February to 8.25 in December. It showed a negative significance with temperature and ammonia nitrogen, positive significance with copper and zinc, and highly significant negative correlation with hydrogen sulfide and total phosphorus. The percentage of Chanda ranga ranged from 0.55 in July to 6.6 in September. It showed a negative significance with nitrite nitrogen and nickel, positive significance with zinc, and highly significant negative correlation with hydrogen sulfide, ammonia nitrogen, and total phosphorus. The percentage of $C$. nama ranged from 2.34 in September to 14.63 in February. It never showed any correlation with environmental parameters.

The percentage of Mugil cephalus ranged from 0.65 in July to 10.72 in April. It showed highly significant negative correlation with lead and manganese. The percentage of Channa marulius ranged from 0.48 in August to 5.86 in 
TABLE 8: Karl Pearson correlation showing the significance (5\%) by relating the number of fishes and physicochemical parameters of Veli Lake.

\begin{tabular}{|c|c|c|c|c|c|}
\hline Name of fish & Temperature & $\mathrm{pH}$ & Salinity & Alkalinity & Dissolved oxygen \\
\hline Oreochromis mossambicus & -0.24 & -0.16 & 0.05 & 0.29 & 0.47 \\
\hline Etroplus suratensis & -0.22 & -0.46 & -0.33 & 0.32 & -0.29 \\
\hline Etroplus maculatus & $0.52^{*}$ & $0.53^{*}$ & -0.27 & -0.01 & -0.19 \\
\hline Terapon jarbua & -0.06 & -0.26 & $0.56^{*}$ & $-0.65^{*}$ & 0.09 \\
\hline Caranx sehfsciatis & -0.39 & -0.45 & 0.44 & -0.26 & 0.39 \\
\hline Caranx ignobilis & -0.38 & -0.12 & 0.13 & 0.11 & 0.47 \\
\hline Chanda ranga & -0.13 & 0.21 & 0.02 & 0.21 & 0.48 \\
\hline Chanda nama & -0.43 & 0.19 & 0.04 & -0.14 & 0.18 \\
\hline Mugil cephalus & -0.40 & -0.45 & $0.61^{*}$ & $-0.71^{*}$ & 0.04 \\
\hline Channa marulius & -0.15 & -0.20 & 0.42 & -0.08 & $0.58^{*}$ \\
\hline Channa striatus & -0.21 & -0.27 & $0.50^{*}$ & -0.25 & $0.60^{*}$ \\
\hline Megalops cyprinoides & -0.09 & -0.33 & -0.04 & -0.02 & $-0.61^{*}$ \\
\hline Gerres filamentosus & $0.53^{*}$ & $0.53^{*}$ & -0.40 & 0.32 & 0.14 \\
\hline Puntius filamentosus & -0.36 & $-0.56^{*}$ & -0.00 & 0.31 & 0.39 \\
\hline Anabas testudineus & $-0.59^{*}$ & -0.25 & $0.62^{*}$ & $-0.54^{*}$ & $0.52^{*}$ \\
\hline Mystus gulio & -0.04 & 0.14 & -0.01 & -0.30 & -0.20 \\
\hline Arius arius & 0.26 & -0.10 & -0.48 & 0.40 & $-0.77^{*}$ \\
\hline Tachysurus subrostratus & -0.32 & -0.44 & $0.61^{*}$ & $-0.61^{*}$ & 0.19 \\
\hline Valamugil cunnesius & -0.39 & $-0.68^{*}$ & 0.43 & -0.22 & 0.48 \\
\hline Liza parsia & -0.27 & -0.35 & 0.11 & -0.20 & -0.22 \\
\hline Elops machnata & -0.08 & -0.24 & -0.30 & 0.38 & 0.29 \\
\hline Hyphorhampus improvis & -0.29 & -0.46 & $0.60^{*}$ & $-0.62^{*}$ & 0.15 \\
\hline Periophthalmus weberi & -0.23 & $-0.56^{*}$ & 0.34 & 0.08 & 0.17 \\
\hline Glossogobius giuris & -0.19 & 0.22 & 0.02 & 0.16 & 0.35 \\
\hline Anguilla bengalensis & -0.24 & 0.12 & 0.17 & 0.02 & 0.38 \\
\hline Austroglossus pectoralis & -0.39 & $-0.62^{*}$ & 0.30 & -0.09 & 0.21 \\
\hline Metapenaeus brevicornis & -0.19 & $-0.54^{*}$ & 0.06 & 0.12 & 0.32 \\
\hline Macrobrachium idella & -0.28 & -0.04 & 0.14 & 0.13 & 0.46 \\
\hline Scylla serrata & -0.13 & -0.46 & -0.27 & $0.59^{*}$ & 0.27 \\
\hline Penaeus monodon & -0.12 & -0.36 & $0.59^{*}$ & $-0.61^{*}$ & 0.08 \\
\hline Penaeus indicus & 0.47 & 0.28 & -0.41 & 0.10 & $-0.70^{* *}$ \\
\hline
\end{tabular}

${ }^{*}$ Significant, ${ }^{* *}$ highly significant.

April. It showed positive significance with manganese and highly significant positive correlation with hydrogen sulfide and total phosphorus. The percentage of $C$. striatus ranged from 0.05 in April to 2.09 in June. It showed positive significance with salinity and negative significance with alkalinity. The percentage of Megalops cyprinoides ranged between 0.89 in November and 5.45 in April. It showed positive significance with temperature and hydrogen sulfide and negative significance with manganese. The percentage of Gerres filamentosus ranged between 0.56 in November and 5.76 in June. It showed negative significance with temperature and positive significance with DO. The percentage of Puntius filamentosus ranged from 0.90 in October to 10.68 in January. No significance was noticed between any environmental parameters.

The percentage of Anabas testudineus ranged between 0.66 in September and 2.03 in April. It showed a negative significance with lead and manganese. The percentage of Mystus gulio ranged between 0.10 in November and 1.52 in April. It showed a significant positive correlation with hydrogen sulfide, negative significance with lead, and highly significant negative correlation with manganese. The percentage of Arius arius ranged from 0.11 in December to 0.71 in April. It showed a positive significance with hydrogen sulfide and nitrite nitrogen and negative significance with copper and manganese. The percentage of Valamugil cunnesius ranged between 0.23 in August and 5.5 in April. It showed a negative significance with lead. The percentage of Liza parsia ranged between 1.79 in December and 2.62 in November. It showed negative significance with ammonia nitrogen and total phosphorus and highly significant positive correlation with copper.

The percentage of Elops machnata ranged from 0.23 in August to 2.82 in April. It showed a positive significance with hydrogen sulfide and negative correlation with manganese. The percentage of Catla catla ranged from 0.05 in February and March to 0.31 in June. It showed negative significance 
TABLE 9: Karl Pearson correlation showing the significance (5\%) by relating the number of fishes and nutrients of Veli Lake.

\begin{tabular}{|c|c|c|c|c|c|}
\hline Name of fish & Hydrogen sulfide & Ammonia nitrogen & Nitrite nitrogen & Phosphate phosphorus & Silicate silicon \\
\hline Oreochromis mossambicus & $-0.57^{*}$ & -0.04 & -0.29 & -0.48 & 0.02 \\
\hline Etroplus suratensis & 0.01 & -0.26 & -0.01 & -0.03 & -0.24 \\
\hline Etroplus maculatus & 0.00 & $0.54^{*}$ & $0.85^{* *}$ & 0.23 & $0.78^{* *}$ \\
\hline Terapon jarbua & -0.12 & -0.05 & 0.00 & -0.16 & -0.24 \\
\hline Caranx sehfsciatis & -0.40 & $-0.60^{*}$ & -0.42 & $-0.52^{*}$ & -0.30 \\
\hline Caranx ignobilis & -0.46 & $-0.60^{*}$ & -0.37 & $-0.56^{*}$ & 0.04 \\
\hline Chanda ranga & -0.30 & -0.27 & -0.26 & -0.32 & 0.24 \\
\hline Chanda nama & -0.07 & 0.05 & -0.23 & -0.01 & 0.09 \\
\hline Mugil cephalus & -0.13 & -0.05 & -0.05 & -0.20 & -0.34 \\
\hline Channa marulius & -0.25 & 0.18 & -0.32 & -0.28 & -0.27 \\
\hline Channa striatus & -0.19 & 0.15 & -0.31 & -0.25 & -0.38 \\
\hline Megalops cyprinoides & 0.42 & -0.05 & 0.05 & 0.33 & -0.34 \\
\hline Gerres filamentosus & -0.19 & 0.40 & $0.66^{* *}$ & -0.06 & $0.77^{* *}$ \\
\hline Puntius filamentosus & $-0.57^{*}$ & $-0.54^{*}$ & -0.49 & $-0.59^{*}$ & -0.35 \\
\hline Anabas testudineus & -0.39 & 0.30 & -0.24 & -0.41 & -0.23 \\
\hline Mystus gulio & $0.62^{*}$ & 0.14 & -0.11 & $0.54^{*}$ & -0.34 \\
\hline Arius arius & $0.59^{*}$ & -0.05 & 0.12 & $0.53^{*}$ & -0.15 \\
\hline Tachysurus subrostratus & -0.24 & -0.20 & -0.12 & -0.34 & -0.30 \\
\hline Valamugil cunnesius & -0.49 & $-0.50^{*}$ & -0.38 & $-0.61^{*}$ & -0.48 \\
\hline Liza parsia & 0.19 & -0.10 & 0.07 & 0.11 & -0.27 \\
\hline Elops machnata & -0.22 & -0.46 & -0.26 & -0.29 & -0.19 \\
\hline Hyphorhampus improvis & -0.21 & -0.16 & -0.08 & -0.30 & -0.33 \\
\hline Periophthalmus weberi & -0.46 & -0.45 & -0.39 & $-0.50^{*}$ & -0.28 \\
\hline Glossogobius giuris & -0.31 & -0.36 & -0.24 & -0.35 & 0.28 \\
\hline Anguilla bengalensis & -0.36 & -0.39 & -0.26 & -0.43 & 0.21 \\
\hline Austroglossus pectoralis & -0.27 & -0.30 & -0.21 & -0.32 & -0.36 \\
\hline Metapenaeus brevicornis & -0.48 & $-0.57^{*}$ & -0.35 & $-0.56^{*}$ & -0.34 \\
\hline Macrobrachium idella & $-0.50^{*}$ & $-0.58^{*}$ & -0.37 & $-0.59^{*}$ & 0.12 \\
\hline Scylla serrata & $-0.50^{*}$ & $-0.58^{*}$ & -0.25 & -0.49 & -0.12 \\
\hline Penaeus monodon & -0.17 & -0.13 & -0.14 & -0.26 & -0.33 \\
\hline Penaeus indicus & $0.92^{* *}$ & 0.09 & 0.09 & $0.83^{* *}$ & -0.21 \\
\hline
\end{tabular}

${ }^{*}$ Significant, ${ }^{* *}$ highly significant.

with total nitrogen. The percentage of Hyporhamphus improvis ranged from 0.51 in October to 4.29 in January. The percentage of Periophthalmus weberi ranged between 0.48 in August and 1.21 in November. It showed positive significance with salinity, negative significance with alkalinity and hydrogen sulfide, and highly significant negative correlation with total phosphorus. The percentage of Gaterius diagramms ranged between 0.06 in November and 0.43 in October. It showed a negative significance with hydrogen sulfide, highly significant positive correlation with organic carbon, and highly significant negative correlation with total phosphorus.

The percentage of Sclatophagus argus was 0.09 in July, 0.25 in November, and 0.69 in December. Rest of the months never reported this species. It showed positive significance with salinity. The percentage of Lutjanus johnii occurred 0.03 only in August. It showed a positive significance with silicate silicon and total nitrogen. The percentage of Scomberomorus guttatus was 0.23 in August, 0.34 in December, and 0.83 in November. The remaining months never reported this species. It showed negative significance with phosphate phosphorus and total phosphorus, positive significance with copper, highly significant positive correlation with salinity, and highly significant negative correlation with alkalinity.

The percentage of Scylla serrata ranged from 0.02 in January to 2.27 in December. It never showed any significance with environmental parameters. The percentage of Penaeus monodon was 0.05 in November, December, and February. It showed positive significance with salinity. The percentage of $P$. indicus ranged between 1.58 in November and 51.23 in March. It showed a significant positive correlation with ammonia nitrogen, phosphate phosphorus, and lead manganese and highly significant negative correlation with zinc. 
TABLE 10: Karl Pearson correlation showing the significance by relating the number of fishes and sediment parameters of Veli Lake.

\begin{tabular}{|c|c|c|c|c|c|c|c|c|}
\hline Name of fish & Organic carbon & Total phosphorus & Total nitrogen & Copper & Lead & Manganese & Nickel & Zinc \\
\hline Oreochromis mossambicus & $0.76^{* *}$ & -0.41 & $0.71^{* *}$ & -0.001 & -0.05 & -0.09 & -0.28 & -0.05 \\
\hline Etroplus suratensis & 0.22 & -0.20 & -0.44 & -0.01 & 0.23 & 0.14 & -0.12 & 0.01 \\
\hline Etroplus maculatus & 0.21 & -0.42 & 0.15 & 0.30 & $-0.81^{* *}$ & $-0.88^{* *}$ & $0.66^{*}$ & $0.83^{* *}$ \\
\hline Terapon jarbua & $-0.55^{*}$ & -0.27 & -0.03 & $0.51^{*}$ & -0.47 & -0.23 & 0.16 & 0.22 \\
\hline Caranx sehfsciatis & -0.42 & -0.01 & -0.24 & $0.56^{*}$ & 0.01 & 0.12 & -0.45 & -0.04 \\
\hline Caranx ignobilis & -0.19 & 0.21 & -0.31 & 0.33 & 0.23 & 0.19 & $-0.63^{*}$ & -0.06 \\
\hline Chanda ranga & 0.00 & 0.46 & -0.06 & -0.08 & 0.30 & 0.20 & -0.34 & -0.10 \\
\hline Chanda nama & -0.21 & 0.07 & 0.08 & -0.29 & 0.17 & -0.01 & -0.18 & -0.01 \\
\hline Mugil cephalus & $-0.64^{*}$ & -0.37 & -0.11 & 0.39 & -0.32 & -0.12 & 0.02 & 0.13 \\
\hline Channa marulius & 0.29 & 0.07 & $0.51^{*}$ & -0.40 & 0.25 & 0.37 & -0.05 & -0.48 \\
\hline Channa striatus & 0.06 & 0.03 & 0.33 & -0.33 & 0.25 & 0.41 & -0.06 & $-0.50^{*}$ \\
\hline Megalops cyprinoides & -0.31 & 0.29 & -0.43 & -0.30 & 0.31 & 0.36 & 0.23 & -0.15 \\
\hline Gerres filamentosus & $0.56^{*}$ & -0.41 & 0.01 & 0.23 & -0.47 & $-0.56^{*}$ & 0.09 & 0.42 \\
\hline Puntius filamentosus & $0.53^{*}$ & -0.43 & 0.16 & 0.29 & 0.06 & 0.05 & $-0.50^{*}$ & -0.05 \\
\hline Anabas testudineus & -0.08 & -0.43 & 0.7 & -0.28 & -0.03 & 0.06 & -0.16 & -0.19 \\
\hline Mystus gulio & $-0.56^{*}$ & 0.32 & -0.9 & -0.31 & 0.32 & 0.31 & 0.08 & -0.37 \\
\hline Arius arius & 0.05 & 0.38 & -0.39 & -0.26 & 0.41 & 0.34 & 0.09 & -0.25 \\
\hline Tachysurus subrostratus & $-0.58^{* *}$ & -0.28 & -0.15 & $0.55^{*}$ & -0.29 & -0.07 & -0.13 & 0.08 \\
\hline Valamugil cunnesius & -0.09 & -0.38 & -0.11 & $0.53^{*}$ & -0.05 & 0.10 & -0.42 & -0.09 \\
\hline Liza parsia & -0.45 & 0.02 & -0.39 & 0.05 & 0.14 & 0.21 & 0.06 & -0.06 \\
\hline Elops machnata & 0.34 & -0.14 & -0.31 & 0.14 & 0.23 & 0.14 & -0.43 & -0.09 \\
\hline Hyphorhampus improvis & $-0.56^{*}$ & -0.33 & -0.13 & $0.53^{*}$ & -0.31 & -0.09 & -0.07 & 0.08 \\
\hline Periophthalmus weberi & 0.23 & -0.17 & 0.37 & 0.46 & -0.08 & 0.08 & -0.30 & -0.09 \\
\hline Glossogobius giuris & -0.14 & 0.39 & -0.17 & 0.11 & 0.23 & 0.14 & -0.47 & -0.05 \\
\hline Anguilla bengalensis & -0.26 & 0.32 & -0.19 & 0.23 & 0.15 & 0.11 & $-0.50^{*}$ & -0.03 \\
\hline Austroglossus pectoralis & -0.04 & -0.24 & 0.07 & 0.34 & 0.03 & 0.15 & -0.18 & -0.11 \\
\hline Metapenaeus brevicornis & 0.24 & -0.42 & -0.16 & $0.51^{*}$ & -0.07 & -0.01 & -0.46 & 0.04 \\
\hline Macrobrachium idella & -0.11 & 0.21 & -0.21 & 0.37 & 0.14 & 0.12 & $-0.63^{*}$ & -0.02 \\
\hline Scylla serrata & $0.71^{* *}$ & -0.34 & 0.05 & 0.39 & 0.03 & -0.03 & -0.36 & 0.11 \\
\hline Penaeus monodon & $-0.50^{*}$ & -0.25 & -0.09 & 0.47 & -0.34 & -0.11 & -0.05 & 0.05 \\
\hline Penaeus indicus & -0.37 & $0.73^{* *}$ & $-0.51^{*}$ & $-0.50^{*}$ & 0.45 & 0.40 & 0.33 & -0.31 \\
\hline
\end{tabular}

${ }^{*}$ Significant, ${ }^{* *}$ highly significant.

The percentage of Macrobrachium idella ranged from 1.58 in December to 3.66 in June. It showed positive significant negative correlation with total nitrogen.

The results of the biodiversity of fish and shellfish resources of the selected estuaries are presented in Table 1. The diversity indexes of Kadinamkulam, Veli, and Poonthura backwaters are presented in Figure 2. Diversity index of Kadinamkulam backwater ranged between 0.60 in August and 2.25 in October. In Veli Lake, it ranged from 0.64 in October to 2.01 in December. In Poonthura backwater, the diversity index ranged between 1.37 in March and 2.59 in December. Species richness of Kadinamkulam, Veli, and Poonthura backwaters is presented in Figure 3. In Kadinamkulam backwater, the species richness ranged from 0.001 in March to 0.003 in October. In Veli lake, it ranged from 0.001 in January and May to 0.0036 in December and in Poonthura it ranged between 0.0009 in March and 0.0026 in December.

The species evenness of Kadinamkulam, Veli, and Poonthura backwaters is presented in Figure 4. The species evenness of Kadinamkulam backwater ranged between 0.23 in August and 0.77 in May. In Veli Lake it ranged from 0.23 in October to 0.64 in December. The species evenness of Poonthura backwater ranged between 0.49 in July and 0.84 in April. The diversity dominance of Kadinamkulam, Veli, and Poonthura backwater is presented in Figure 5. In Kadinamkulam backwater, the biodiversity dominance ranged from 0.18 in September to 0.78 in August. In Veli Lake, it ranged from 0.24 in December to 0.79 in October. The diversity dominance of Poonthura backwater ranged between 0.12 in December and 0.45 in September. 
TABLE 11: Karl Pearson correlation showing the significance (5\%) by relating the number of fishes and physicochemical parameters of Poonthura backwater.

\begin{tabular}{|c|c|c|c|c|c|}
\hline Name of fish & Temperature & $\mathrm{PH}$ & Salinity & Alkalinity & Dissolved oxygen \\
\hline Oreochromis mossambicus & $-0.50^{*}$ & 0.01 & -0.01 & -0.18 & 0.29 \\
\hline Etroplus suratensis & 0.31 & 0.16 & -0.18 & 0.30 & -0.44 \\
\hline Etroplus maculatus & -0.25 & 0.33 & $0.63^{*}$ & $-0.50^{*}$ & 0.45 \\
\hline Terapon jarbua & 0.14 & -0.15 & 0.26 & -0.03 & -0.44 \\
\hline Caranx sehfsciatis & -0.20 & -0.45 & -0.15 & 0.13 & -0.44 \\
\hline Caranx ignobilis & $-0.54^{*}$ & -0.39 & 0.21 & -0.24 & -0.43 \\
\hline Chanda ranga & -0.48 & -0.31 & -0.16 & 0.07 & -0.29 \\
\hline Chanda nama & 0.40 & -0.05 & -0.19 & 0.32 & -0.49 \\
\hline Mugil cephalus & -0.13 & 0.26 & 0.43 & -0.33 & 0.09 \\
\hline Channa marulius & 0.46 & $0.52^{*}$ & -0.16 & 0.23 & 0.21 \\
\hline Channa striatus & -0.26 & -0.35 & $0.52^{*}$ & $-0.58^{*}$ & 0.11 \\
\hline Megalops cyprinoides & $0.51^{*}$ & 0.03 & -0.19 & 0.34 & 0.07 \\
\hline Gerres filamentosus & $-0.61^{*}$ & 0.35 & 0.08 & -0.32 & $0.51^{*}$ \\
\hline Puntius filamentosus & 0.42 & 0.01 & -0.25 & 0.33 & -0.50 \\
\hline Anabas testudineus & 0.12 & -0.04 & -0.30 & 0.36 & -0.08 \\
\hline Mystus gulio & 0.38 & 0.25 & -0.19 & 0.35 & 0.01 \\
\hline Arius arius & 0.38 & 0.36 & -0.10 & 0.28 & 0.27 \\
\hline Valamugil cunnesius & -0.45 & -0.03 & 0.03 & -0.11 & 0.11 \\
\hline Liza parsia & -0.21 & 0.09 & 0.32 & -0.17 & -0.21 \\
\hline Elops machnata & 0.41 & 0.20 & -0.24 & 0.45 & -0.04 \\
\hline Catla catla & -0.28 & 0.35 & 0.08 & -0.22 & 0.29 \\
\hline Hyphorhampus improvis & -0.05 & -0.09 & -0.12 & 0.15 & -0.47 \\
\hline Periophthalmus weberi & -0.36 & -0.40 & $0.64^{*}$ & $-0.57^{*}$ & -0.10 \\
\hline Gaterius diagramms & -0.18 & -0.30 & -0.25 & 0.20 & -0.15 \\
\hline Scatophagus argus & -0.26 & -0.30 & $0.60^{*}$ & -0.44 & -0.28 \\
\hline Lutjanus johnii & -0.36 & 0.17 & -0.17 & 0.01 & 0.11 \\
\hline Scomberomorus guttatus & -0.34 & -0.34 & $0.82^{* *}$ & $-0.76^{* *}$ & -0.30 \\
\hline Scylla serrata & 0.13 & -0.36 & 0.38 & -0.11 & -0.36 \\
\hline Penaeus monodon & -0.09 & -0.45 & $0.58^{*}$ & -0.46 & -0.47 \\
\hline Penaeus indicus & 0.49 & -0.11 & -0.12 & 0.12 & 0.18 \\
\hline Macrobrachium idella & -0.34 & $0.55^{*}$ & 0.10 & -0.12 & $0.56^{*}$ \\
\hline
\end{tabular}

${ }^{*}$ Significant, ${ }^{* *}$ highly significant.

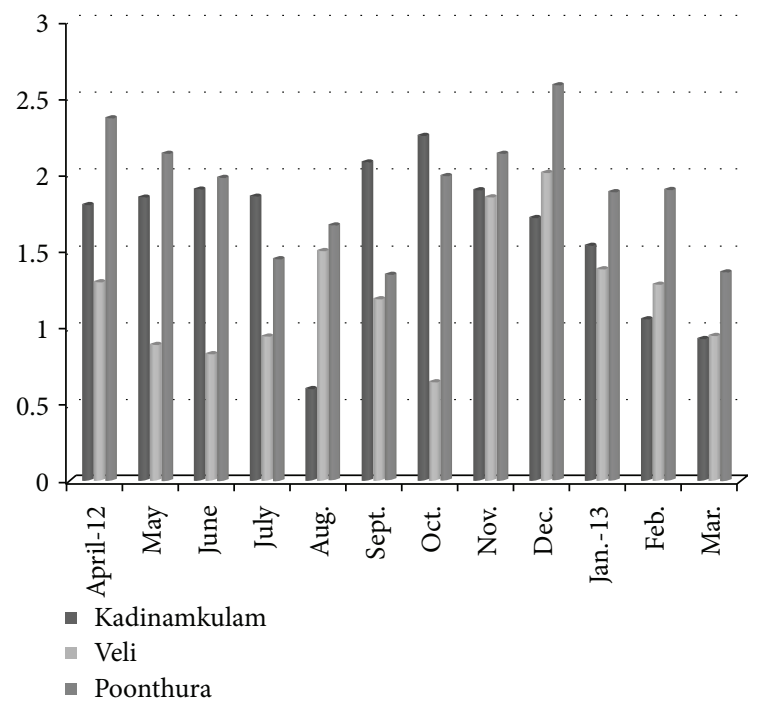

FIGURE 2: Diversity index of the fin and shellfishes present in the selected backwaters of Kerala.

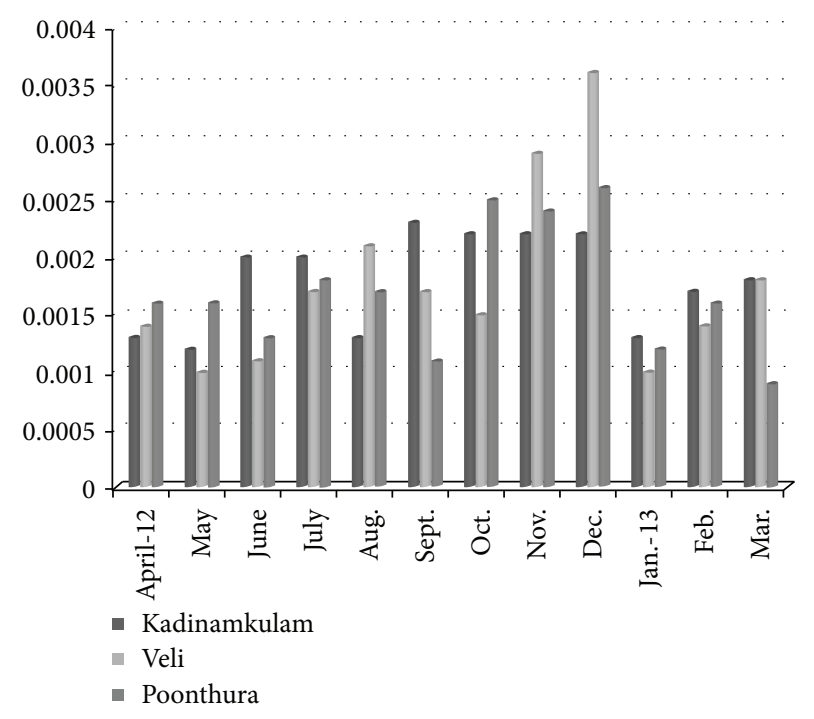

FIGURE 3: Species richness of the fin and shellfishes present in the selected backwaters of Kerala. 
TABLE 12: Karl Pearson correlation showing the significance (5\%) by relating the number of fishes and nutrients of Poonthura backwater.

\begin{tabular}{|c|c|c|c|c|c|}
\hline Name of fish & Hydrogen sulfide & Ammonia nitrogen & Nitrite nitrogen & Phosphate phosphorus & Silicate silicon \\
\hline Oreochromis mossambicus & $-0.67^{*}$ & -0.27 & $-0.53^{*}$ & -0.31 & -0.04 \\
\hline Etroplus suratensis & 0.46 & -0.13 & $0.52^{*}$ & -0.07 & 0.12 \\
\hline Etroplus maculatus & 0.21 & 0.30 & 0.30 & -0.40 & 0.04 \\
\hline Terapon jarbua & 0.03 & -0.32 & 0.23 & -0.06 & 0.02 \\
\hline Caranx sehfsciatis & $-0.68^{*}$ & -0.49 & -0.46 & -0.02 & -0.41 \\
\hline Caranx ignobilis & $-0.79^{* *}$ & $-0.63^{*}$ & -0.45 & -0.49 & -0.20 \\
\hline Chanda ranga & $-0.78^{* *}$ & $-0.71^{* *}$ & $-0.58^{*}$ & -0.15 & -0.06 \\
\hline Chanda nama & 0.27 & 0.00 & 0.38 & 0.07 & -0.11 \\
\hline Mugil cephalus & 0.36 & -0.08 & 0.33 & -0.13 & 0.23 \\
\hline Channa marulius & $0.87^{* *}$ & 0.32 & $0.68^{*}$ & 0.20 & 0.25 \\
\hline Channa striatus & -0.12 & 0.18 & -0.36 & 0.02 & -0.37 \\
\hline Megalops cyprinoides & $0.53^{*}$ & 0.18 & 0.36 & 0.48 & 0.09 \\
\hline Gerres filamentosus & 0.08 & 0.05 & -0.32 & -0.06 & 0.22 \\
\hline Puntius filamentosus & 0.24 & 0.04 & 0.39 & -0.06 & -0.14 \\
\hline Anabas testudineus & 0.076 & -0.21 & -0.05 & 0.29 & 0.11 \\
\hline Mystus gulio & $0.53^{*}$ & 0.01 & 0.47 & 0.30 & 0.36 \\
\hline Arius arius & $0.56^{*}$ & 0.31 & $0.53^{*}$ & 0.19 & 0.33 \\
\hline Valamugil cunnesius & -0.16 & -0.19 & -0.36 & -0.02 & -0.17 \\
\hline Liza parsia & -0.23 & $-0.62^{*}$ & 0.19 & -0.24 & 0.4 \\
\hline Elops machnata & $0.53^{*}$ & -0.06 & 0.47 & 0.41 & 0.40 \\
\hline Catla catla & 0.35 & 0.10 & 0.06 & 0.09 & 0.05 \\
\hline Hyphorhampus improvis & -0.19 & -0.17 & 0.01 & -0.36 & -0.14 \\
\hline Periophthalmus weberi & $-0.68^{*}$ & -0.19 & -0.41 & -0.34 & -0.22 \\
\hline Gaterius diagramms & $-0.56^{*}$ & -0.38 & -0.47 & 0.19 & -0.21 \\
\hline Scatophagus argus & -0.31 & -0.08 & -0.03 & -0.45 & -0.34 \\
\hline Lutjanus johnii & -0.26 & -0.33 & -0.28 & -0.17 & $0.57^{*}$ \\
\hline Scomberomorus guttatus & -0.48 & -0.34 & -0.17 & $-0.58^{*}$ & -0.20 \\
\hline Scylla serrata & 0.06 & -0.12 & 0.15 & 0.09 & -0.16 \\
\hline Penaeus monodon & -0.25 & -0.07 & -0.02 & -0.28 & -0.43 \\
\hline Penaeus indicus & 0.36 & $0.58^{*}$ & 0.09 & $0.51^{*}$ & 0.01 \\
\hline Macrobrachium idella & 0.30 & 0.17 & 0.22 & -0.00 & 0.23 \\
\hline
\end{tabular}

${ }^{*}$ Significant, ${ }^{* *}$ highly significant.

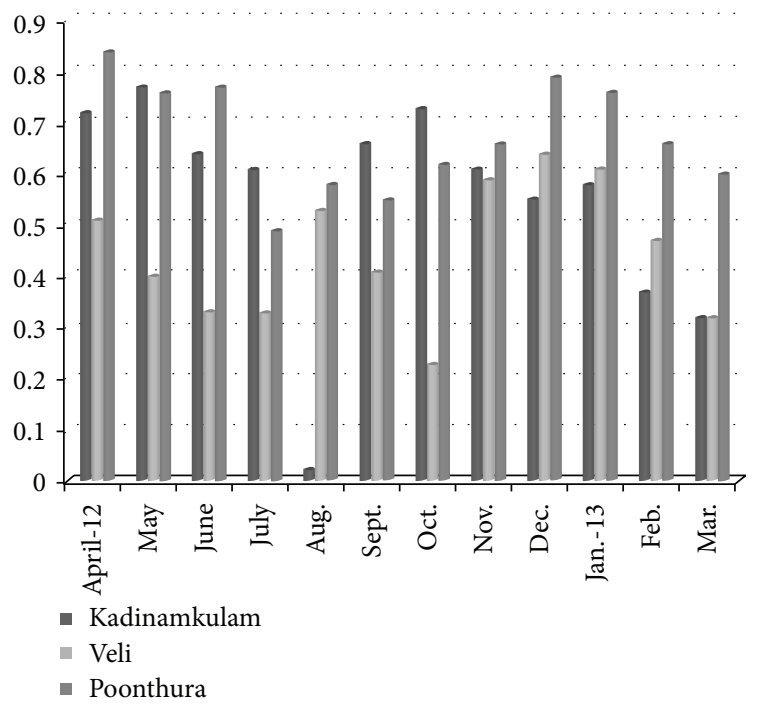

FIGURE 4: Species evenness of the fin and shellfishes present in the selected backwaters of Kerala.

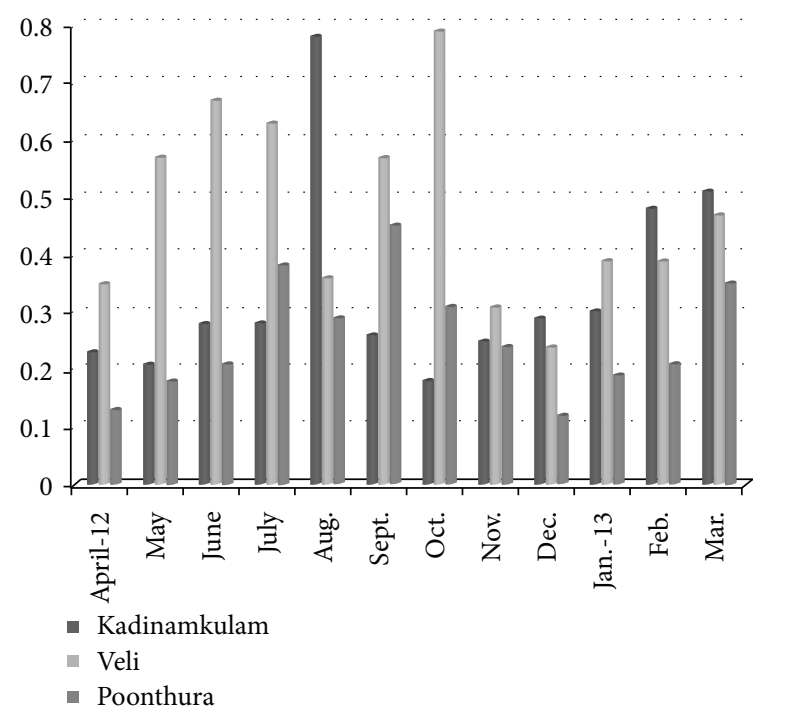

FIGURE 5: Species dominance of the fin and shellfishes present in the selected backwaters of Kerala. 
TABLE 13: Karl Pearson correlation showing the significance (5\%) by relating the number of fishes and sediment parameters of Poonthura backwater.

\begin{tabular}{|c|c|c|c|c|c|c|c|c|}
\hline Name of fish & Organic carbon & Total phosphorus & Total nitrogen & Copper & Lead & Manganese & Nickel & Zinc \\
\hline Oreochromis mossambicus & 0.11 & $-0.73^{* *}$ & -0.29 & 0.18 & -0.06 & 0.23 & $-0.65^{*}$ & 0.11 \\
\hline Etroplus suratensis & 0.00 & $0.53^{*}$ & 0.42 & -0.08 & -0.02 & -0.33 & 0.31 & 0.15 \\
\hline Etroplus maculatus & -0.45 & -0.03 & -0.38 & -0.15 & $-0.50^{*}$ & -0.43 & 0.08 & -0.04 \\
\hline Terapon jarbua & 0.35 & -0.16 & 0.30 & 0.17 & $-0.77^{* *}$ & $-0.72^{* *}$ & 0.07 & $0.73^{* *}$ \\
\hline Caranx sehfsciatis & $0.79^{* *}$ & $-0.72^{* *}$ & -0.10 & 0.48 & -0.07 & 0.18 & -0.30 & $0.65^{*}$ \\
\hline Caranx ignobilis & 0.24 & $-0.80^{* *}$ & 0.33 & $0.51^{*}$ & -0.08 & 0.18 & -0.37 & $0.57^{*}$ \\
\hline Chanda ranga & 0.49 & $-0.86^{* *}$ & 0.16 & 0.46 & -0.05 & 0.18 & $-0.66^{*}$ & $0.55^{*}$ \\
\hline Chanda nama & 0.21 & 0.41 & 0.29 & -0.10 & -0.11 & -0.31 & 0.46 & 0.31 \\
\hline Mugil cephalus & -0.24 & 0.09 & -0.00 & 0.01 & $0.81^{* *}$ & $-0.77^{* *}$ & 0.01 & 0.33 \\
\hline Channa marulius & -0.22 & $0.78^{* *}$ & -0.23 & -0.36 & -0.20 & $-0.53^{*}$ & 0.25 & -0.27 \\
\hline Channa striatus & -0.18 & -0.17 & -0.18 & 0.21 & 0.07 & 0.33 & 0.18 & -0.16 \\
\hline Megalops cyprinoides & 0.07 & 0.36 & -0.06 & -0.33 & -0.32 & $-0.62^{*}$ & 0.09 & 0.01 \\
\hline Gerres filamentosus & -0.39 & -0.04 & -0.15 & -0.28 & -0.19 & -0.05 & -0.25 & -0.16 \\
\hline Puntius filamentosus & 0.20 & 0.49 & 0.25 & -0.04 & 0.20 & 0.00 & 0.49 & 0.11 \\
\hline Anabas testudineus & 0.36 & -0.13 & 0.16 & -0.30 & $-0.53^{*}$ & $-0.65^{*}$ & -0.25 & 0.45 \\
\hline Mystus gulio & 0.07 & 0.33 & 0.12 & -0.35 & $-0.56^{*}$ & $-0.84^{* *}$ & 0.00 & 0.23 \\
\hline Arius arius & -0.17 & 0.41 & -0.05 & $-0.54^{*}$ & -0.38 & $-0.69^{*}$ & 0.12 & -0.07 \\
\hline Valamugil cunnesius & 0.18 & -0.41 & -0.19 & -0.13 & $-0.55^{*}$ & -0.40 & -0.30 & 0.46 \\
\hline Liza parsia & 0.22 & $-0.50^{*}$ & 0.07 & $0.73^{* *}$ & -0.42 & -0.24 & -0.45 & 0.45 \\
\hline Elops machnata & 0.19 & 0.26 & 0.14 & -0.28 & $-0.50^{*}$ & $-0.81^{* *}$ & -0.06 & 0.24 \\
\hline Catla catla & -0.13 & 0.21 & $-0.50^{*}$ & 0.10 & -0.12 & -0.02 & 0.01 & -0.13 \\
\hline Hyphorhampus improvis & 0.11 & 0.03 & 0.43 & 0.01 & 0.31 & 0.25 & 0.21 & 0.17 \\
\hline Periophthalmus weberi & 0.17 & $-0.76^{* *}$ & 0.02 & 0.44 & -0.32 & 0.14 & -0.11 & 0.39 \\
\hline Gaterius diagramms & $0.73^{* *}$ & $-0.70^{* *}$ & -0.26 & 0.34 & -0.08 & 0.13 & -0.45 & 0.46 \\
\hline Scatophagus argus & -0.04 & -0.35 & 0.10 & 0.31 & -0.13 & 0.05 & 0.22 & 0.31 \\
\hline Lutjanus johnii & -0.34 & -0.17 & $0.59^{*}$ & -0.10 & 0.19 & 0.19 & -0.47 & -0.17 \\
\hline Scomberomorus guttatus & -0.12 & $-0.50^{*}$ & 0.30 & $0.55^{*}$ & -0.48 & -0.08 & 0.01 & 0.45 \\
\hline Scylla serrata & 0.28 & -0.19 & 0.14 & 0.23 & -0.43 & -0.40 & 0.20 & 0.46 \\
\hline Penaeus monodon & 0.01 & -0.16 & 0.21 & 0.42 & -0.15 & 0.07 & 0.45 & 0.38 \\
\hline Penaeus indicus & -0.30 & $0.60^{*}$ & 0.02 & -0.23 & $0.70^{*}$ & $0.51^{*}$ & 0.47 & $-0.77^{* *}$ \\
\hline Macrobrachium idella & -0.14 & 0.00 & $-0.76^{* *}$ & 0.03 & -0.11 & -0.07 & -0.19 & -0.21 \\
\hline
\end{tabular}

${ }^{*}$ Significant, ${ }^{* *}$ highly significant.

\section{Discussion}

Estuaries play a significant role as nursery grounds for fishes and prawns in view of their high productivity and also shelter to the juveniles. Due to slow changes in climatic and coastal geomorphic conditions, the estuarine systems have undergone some changes, particularly with regard to sedimentation and sand bar formation [10]. Most of the fish species collected from the environments are transient forms inhabiting the estuarine and riverine environments. Few species are riverine while others are marine forms [8]. The commercially important groups which contribute to the major catches belong to the estuarine habitat which are highly seasonal, since the catches depend upon the adjacent sea and river.

Many species use the estuarine environments as temporary feeding grounds principally of juveniles. These major biological features are linked to the estuarine ecosystem. Therefore, it is not justified to limit the census of estuarine species to only those species with a fully estuarine biological cycle [11]. The concept of hot spots (species richness) largely based on concentration of species in an area plays an important role in nature that result from the exchanges between biotic and abiotic components in various ecosystems [12].

Man-made changes like construction of barrages, dams, and canals across most of the rivers and reclamation of land for various purposes have led to environmental changes in the estuarine system. In addition to this, the increase of effluent discharge by industrial, agricultural, and domestic means has brought out changes in the biotic community of estuaries [13]. It is imperative to understand the biodiversity of the habitats so as to understand resource potential and to exploit natural living resources for the welfare of mankind. The fauna of brackish water system is generally composed of marine and freshwater organisms which are adapted to waters of different salinities besides truly resident estuarine species [5]. A total of 33 species of fish and shellfish from all the three backwaters 
(30 species from Kadinamkulam, 31 from Veli, and 32 species in Poonthura) were recorded in the present study.

The diversity index (2.9) was highest in Poonthura backwater because additional five species were reported compared to the other two estuaries. The factors superimpose on hydrology influence the species diversity by different criteria such as biogeography, size of the estuarine zone, habitat diversity, and openness to adjacent ecosystem [14]. The diversity index of Kadinamkulam and Veli $(2.25,2.01)$ was low when compared to Poonthura. The limnological conditions and morphology of the aquatic macrophyte species provide sufficient habitat heterogeneity to give very low or null index values. Thus, environmental conservation measures should be more effective in promoting the conservation of the species, given the high levels of biological diversity found in the habitats studied [13]. It suggests that extreme climatic variations may result in an alteration of fauna of different origin and increasing the global temperature may also result in loss of freshwater species [11].

The factors related to zoogeography such as restricted distribution, wider distribution with preferential mass migration to selected localities, and less conducive biotopes can also cause rarity of species [15]. The species richness was high in Veli (0.0036) and in Kadinamkulam and Poonthura it was more or less the same $(0.0022,0.0025)$. Salinity exposures included both rapid and gradual change events. Results show adverse effects of acute, abrupt salinity changes in fish survival and development due to salinity stress [16]. The species richness of estuaries is the number of the particular species which encountered their limits at the particular ecosystem [17]. The high species richness of Veli was due to two antagonistic hydrological processes such as penetration of fish fauna from marine or freshwater origin and permanent resident species which make up the bulk of the catches.

Many other species use the estuarine environments as a temporary feeding ground principally of juveniles. These major biological features are linked to the estuarine ecosystem. Therefore, it is not justified to limit the census of estuarine species to only those species with a fully estuarine biological cycle [18]. The concept of hot spots (species richness) largely based on concentration of species in an area plays an important role in nature that results from the exchanges between biotic and abiotic components in various ecosystems [19].

The species evenness was more in Poonthura (0.84) than Kadinamkulam (0.77) and Veli Lake (0.64). The low evenness recorded in Veli was due to the dominance of certain species which reduced the chances of survival of more species because of the nonavailability of feeding and breeding grounds for all the inhabitants and due to pollution stress. Relationships between biomass and evenness varied and depended on the identity of the dominant species. Wilsey and Potvin [20] reported that changes in evenness occur with little or no changes in species richness and these point out the importance of evenness as a component of diversity. The present study also agreed with this statement. Reduction in evenness occurs due to the response of environmental changes which produce indirect effects on estuarine productivity.
Biodiversity dominance was more or less same and high in Kadinamkulam and Veli Lake $(0.78,0.78)$ and less in Poonthura (0.45) back water. This shows an inverse relationship with evenness of the species. The fittest species such as Oreochromis mossambicus and Penaeus indicus resists the environmental degradation up to an extreme extent and supports the diversity dominance of the ecosystem and replaces the sensitive species. Highly contaminated sites showed substantially lower abundances of surface-deposit feeders and herbivores and higher abundances of subsurface-deposit feeders and omnivores. Salinity was also a significant factor affecting the community, being responsible for seasonal variations in the macrobenthic assemblages [21].

Threats to global aquatic biodiversity are by overexploitation; water pollution; flow modification; destruction or degradation of habitat; and invasion by exotic species. Their combined and interacting influences have resulted in population declines and range reduction of biodiversity, and the conservation of biodiversity is complicated by the landscape position of rivers and wetlands [22]. The estuarine species composition and abundance of the fauna depend both on river hydrological regimes and seawater biogeographic regions [23]. In the present study, more or less same species composition of the three backwaters was due to similar habitat type, geomorphology, and similar climatic conditions prevailing around all the backwaters. Ecological complexity enhances biodiversity through evolutionary and biogeographical processes and its degradation quickly causes the diversity in phenotypic and genotypic traits to decline [10].

\section{Conflict of Interests}

The author declares that there is no conflict of interests regarding the publication of this paper.

\section{References}

[1] A. Charrier, F. Fridlansky, and J. C. Mounolou, "Biological diversity and genetic resources," in Biodiversity, Science and Development Towards a New Partnership, F. Dicastri and T. Younes, Eds., pp. 226-229, 1996.

[2] J. C. Currie, K. J. Sink, P. le Noury, and G. M. Branch, "Comparing fish communities in sanctuaries, partly protected areas and open-access reefs in South-East Africa," African Journal of Marine Science, vol. 34, no. 2, pp. 269-281, 2012.

[3] K. N. Ganeshaiah, K. Chandrashekara, and A. R. V. Kumar, "Avalanche index: a new measure of biodiversity based on biological heterogeneity of the communities," Current Science, vol. 73, no. 2, pp. 128-133, 1997.

[4] S. Villéger, J. R. Miranda, D. F. Hernandez, and D. Mouillot, "Low functional beta-diversity despite high taxonomic betadiversity among tropical estuarine fish communities," PLoS ONE, vol. 7, no. 7, Article ID e40679, 2012.

[5] N. B. Nair, K. K. Kumar, J. R. Nair, P. K. Azis, K. Dharmaraj, and M. Arunachalam, "Ecology of Indian Estuaries XI. A preliminary survey of the fishery resources of the Ashtamudi estuarine system," Fisheries Technology, vol. 20, pp. 75-83, 1983.

[6] L. Ababouch, "Assuring fish safety and quality in international fish trade," Marine Pollution Bulletin, vol. 53, pp. 561-568, 2006. 
[7] P. K. Talwar and A. G. Jhingran, Inland Fishes of India and Adjacent Countries, vol. 1-2, Oxford and IBH Publishing, New Delhi, India, 1991.

[8] S. H. M. Butchart, M. Walpole, B. Collen et al., "Global biodiversity; indicators of recent declines," Science, vol. 328, pp. 1164$1168,2010$.

[9] C. Cai, X. Gu, Y. Ye, C. Yang, X. Dai, and D. Chen, "Assessment of pollutant loads discharged from aquaculture ponds around Taihu Lake, China," Aquaculture Research, vol. 44, no. 5, pp. 795-806, 2012.

[10] C. Campagna, F. T. Short, B. A. Polidoro et al., "Gulf of Mexico oil blowout increases risks to globally threatened species," BioScience, vol. 61, no. 5, pp. 393-397, 2011.

[11] E. Baran, "Biodiversity of estuarine fish faunas in West Africa," Naga, vol. 23, no. 4, pp. 4-9, 2000.

[12] J. S. Singh, "The biodiversity crisis: a multifaceted review," Current Science, vol. 82, no. 6, pp. 638-647, 2002.

[13] E. B. Pacheco and C. J. Da-Silva, "Fish associated with aquatic macrophytes in the Chacororé-Sinhá Mariana Lake system and Mutum River, Pantanal of Mato Grosso, Brazil," Brazilian Journal of Biology, vol. 69, no. 1, pp. 101-108, 2009.

[14] J. J. Albaret, “Les Peuplements des estuaries et lagunes," in Les poissons des eaux continentales africaines, C. Lévêque and D. Paugy, Eds., pp. 325-349, IRD editions, Paris, France, 1999.

[15] P. D. Cowley, A. R. Childs, and H. R. Bennett, "The trouble with estuarine fisheries in temperate South Africa, illustrated by a case study on the Sundays Estuary," African Journal of Marine Science, vol. 35, no. 1, pp. 117-128, 2013.

[16] P. M. Bachman and G. M. Rand, "Effects of salinity on native estuarine fish species in South Florida," Ecotoxicology, vol. 17, no. 7, pp. 591-597, 2008.

[17] X. Shan, P. Sun, X. Jin, X. Li, and F. Dai, "Long-term changes in fish assemblage structure in the yellow river estuary ecosystem, China," Marine and Coastal Fisheries, vol. 5, no. 1, pp. 65-78, 2013.

[18] L. W. Botsford, J. C. Castilla, and C. H. Peterson, "The management of fisheries and marine ecosystems," Science, vol. 277, no. 5325, pp. 509-515, 1997.

[19] T. B. Hoareau, E. Boissin, G. Paulay, and J. H. Bruggemann, “The Southwestern Indian Ocean as a potential marine evolutionary hotspot: perspectives from comparative phylogeography of reef brittle-stars," Journal of Biogeography, vol. 40, no. 11, pp. 21672179, 2013.

[20] B. J. Wilsey and C. Potvin, "Biodiversity and ecosystem functioning: Importance of species evenness in an old field," Ecology, vol. 81, no. 4, pp. 887-892, 2000.

[21] M. Nunes, J. P. Coelho, P. G. Cardoso, M. E. Pereira, A. C. Duarte, and M. A. Pardal, "The macrobenthic community along a mercury contamination in a temperate estuarine system (Ria de Aveiro, Portugal)," Science of the Total Environment, vol. 405, no. 1-3, pp. 186-194, 2008.

[22] D. Dudgeon, A. H. Arthington, M. O. Gessner et al., "Freshwater biodiversity: importance, threats, status and conservation challenges," Biological Reviews of the Cambridge Philosophical Society, vol. 81, no. 2, pp. 163-182, 2006.

[23] F. Marsac, R. Barlow, J. F. Ternon, F. Ménard, and M. Roberts, "Ecosystem functioning in the Mozambique channel: synthesis and future research," Deep-Sea Research Part II: Topical Studies in Oceanography, vol. 100, pp. 212-220, 2014. 

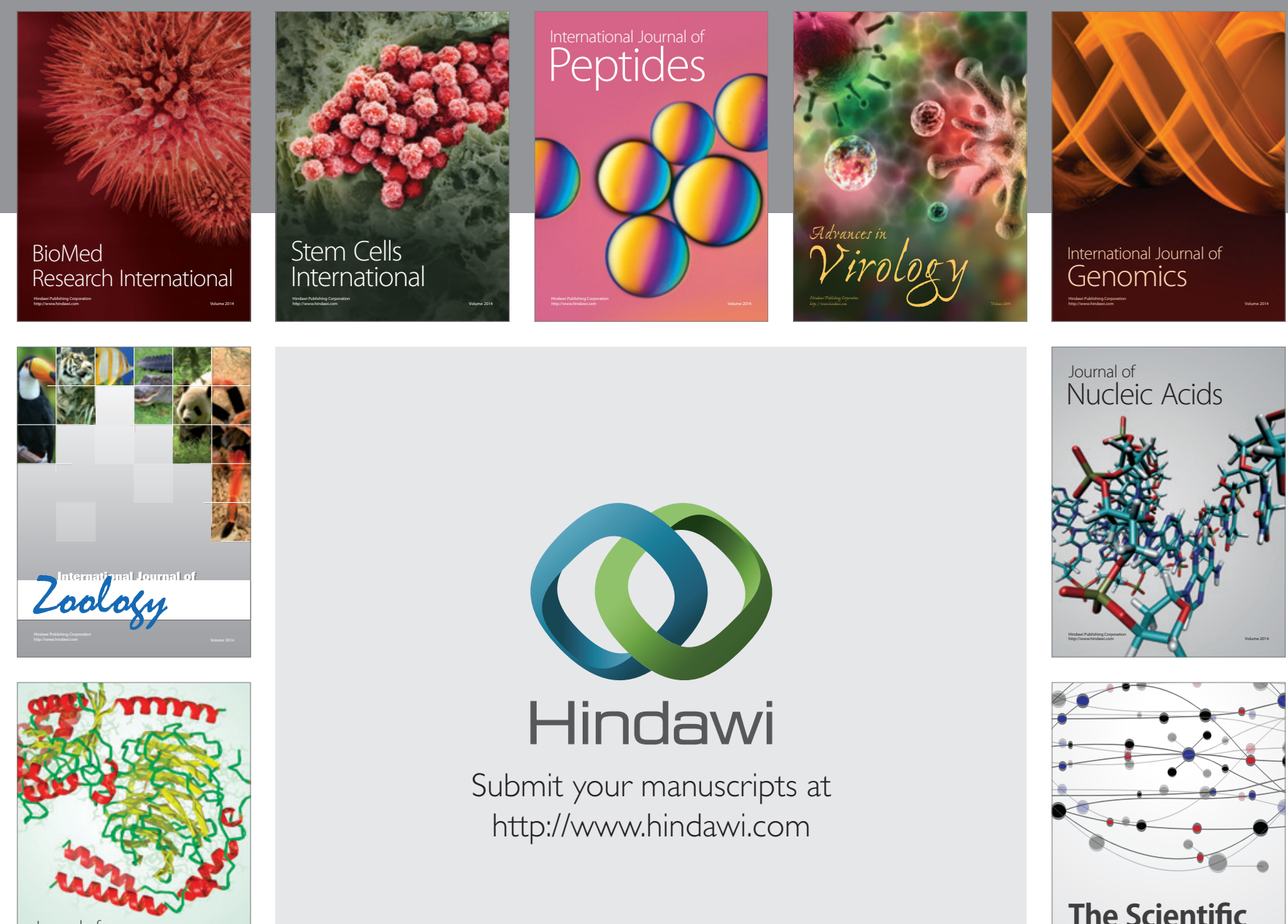

Submit your manuscripts at

http://www.hindawi.com

Journal of
Signal Transduction
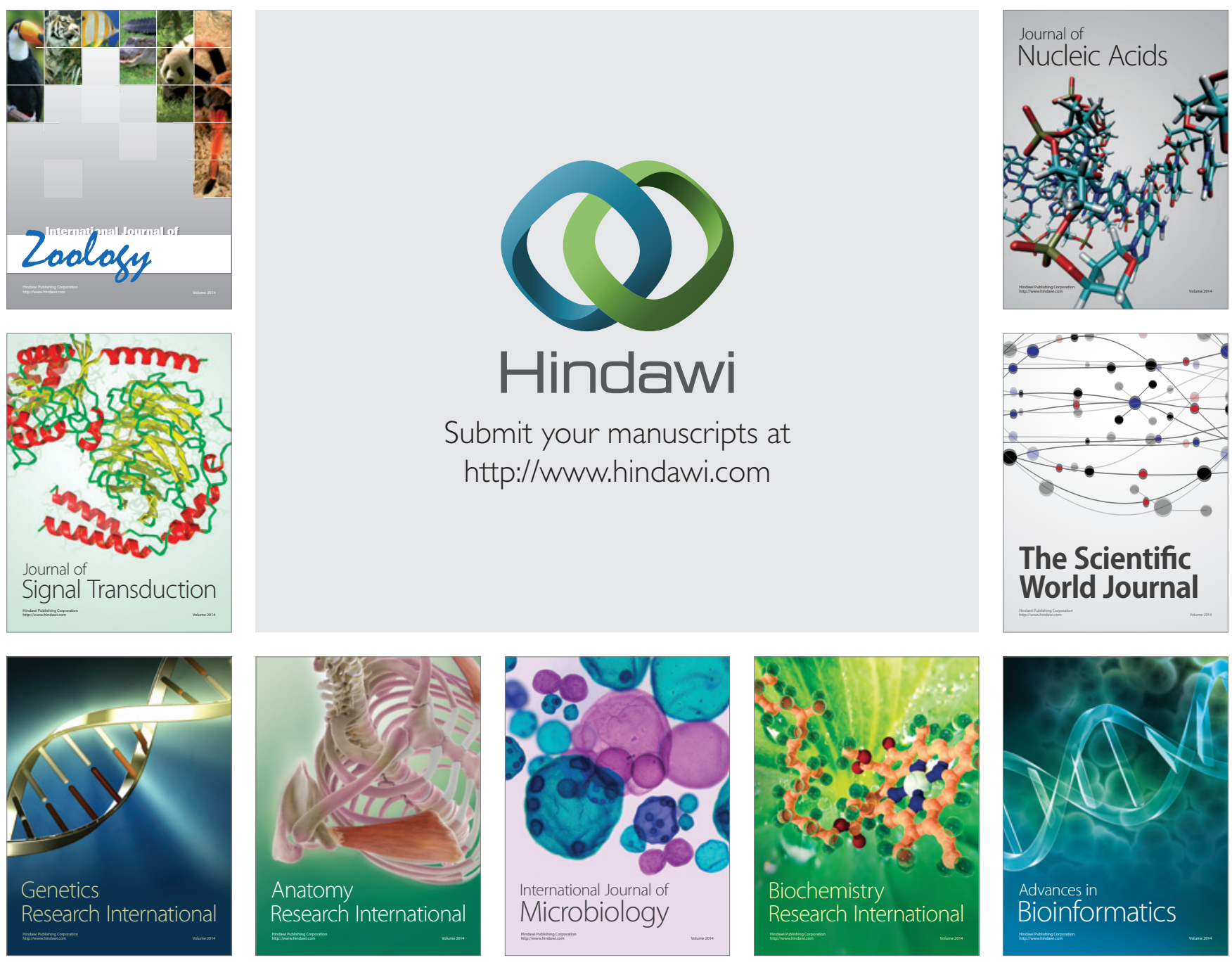

The Scientific World Journal
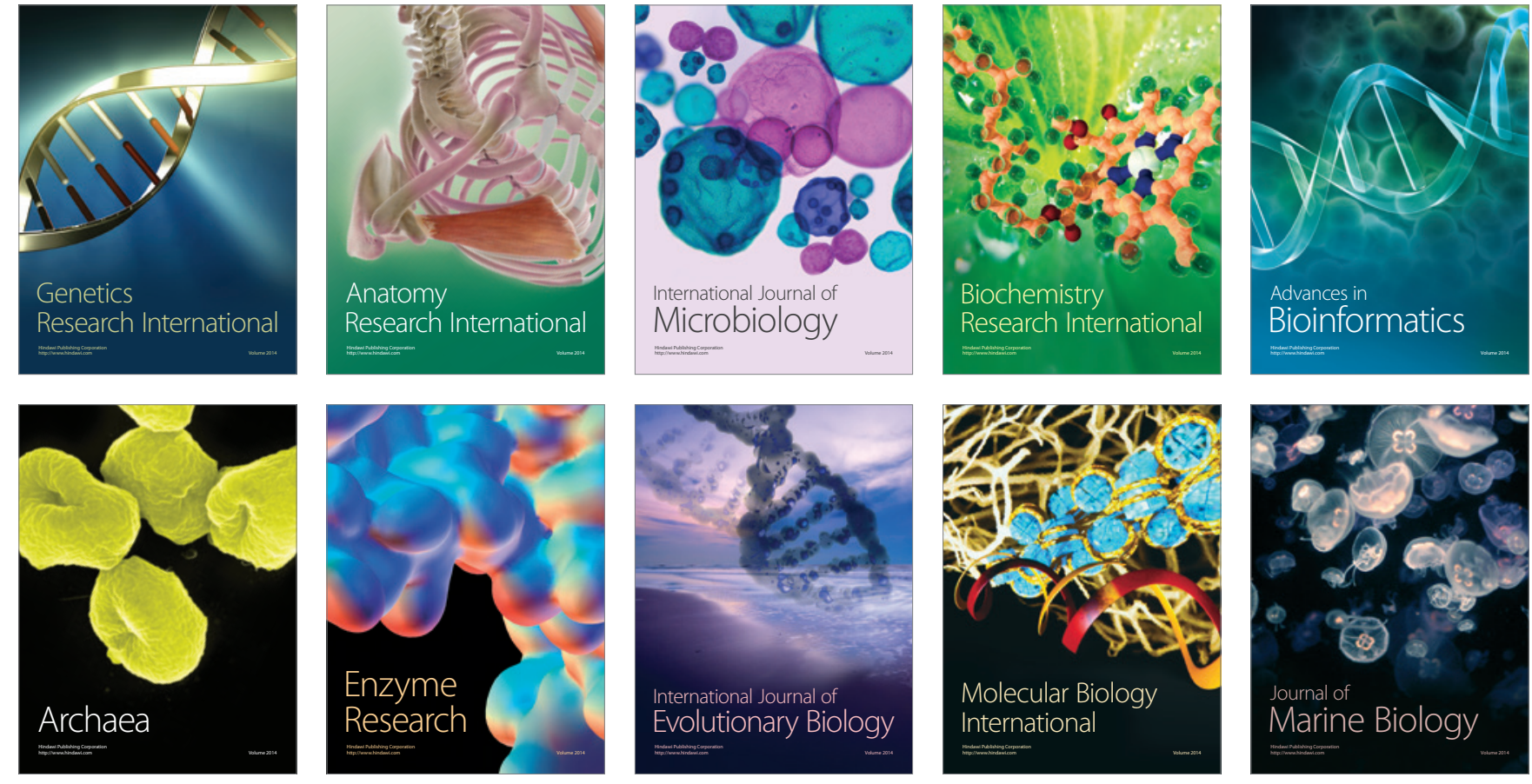